\title{
Assessment of Pseudorange Multipath at Continuous GPS Stations in Mexico
}

\author{
G. Esteban Vázquez ${ }^{1}$, Rick Bennett ${ }^{2}$, Joshua Spinler ${ }^{2}$ \\ ${ }^{1}$ Faculty of the Earth and Space Sciences, The Autonomous University of Sinaloa, Culiacan, Mexico; ${ }^{2}$ Department of Geosciences, \\ The University of Arizona, Tucson, USA. \\ Email: estebanv_99@yahoo.com
}

Received April 26 $6^{\text {th }}, 2013$; revised May 24 $4^{\text {th }}, 2013$; accepted June $7^{\text {th }}, 2013$

Copyright (C 2013 G. Esteban Vázquez et al. This is an open access article distributed under the Creative Commons Attribution License, which permits unrestricted use, distribution, and reproduction in any medium, provided the original work is properly cited.

\begin{abstract}
We conducted a study to quantify the amount of pseudorange multipath at continuous Global Positioning System (CGPS) stations in the Mexican territory. These CGPS stations serve as reference stations enabling rapid high-precision three-dimensional positioning capabilities, supporting a number of commercial and public safety applications. We studied CGPS data from a large number of publicly available networks spanning Mexico. These include the RGNA (National Active Geodetic Network) administered by INEGI (National Institute of Statistics and Geography), the PBO network (Plate Boundary Observatory) funded by the National Science Foundation (NSF) and operated by UNAVCO (University NAVstar Consortium), the Southern California Integrated GPS Network (SCIGN), which is a collaboration effort of the United States Geological Survey (USGS), Scripps Institution of Oceanography and the Jet Propulsion Laboratory (JPL), the UNAM network, operated by the National Seismological System (SSN) and the Institute of Geophysics of the National Autonomous University of Mexico (UNAM), the Suominet Geodetic Network (SNG) and the CORS (Continuously Operating Reference Station) network, operated by the Federal Aviation Administration (FAA). We evaluated a total of 53 CGPS stations, where dual-frequency geodetic-grade receivers collected GPS data continuously during the period from 1994 to 2012. Despite carefully selected locations, all GPS stations are, to some extent, affected by the presence of signal multipath. For GPS network users that rely on pseudorange observables, the existence of pseudorange multipath could be a critical source of error depending on the time scale of the application. Thus, to identify the most and the least affected GPS stations, we analyzed the averaged daily root mean square pseudorange multipath variations (MP1-RMS and MP2-RMS) for all feasible satellites tracked by the CGPS networks. We investigated the sources of multipath, including changes associated with hardware replacement (i.e., receiver and antenna type) and receiver firmware upgrades.
\end{abstract}

Keywords: Pseudorange; Multipath; GPS; Network

\section{Introduction}

CGPS sites from the RGNA, PBO, SCIGN, UNAM, SNG and CORS networks considered in this study are located throughout the Mexican territory. All of these stations operate continuously, serving as reference stations for high-precision three-dimensional geodetic positioning applications based on GPS measurements. These reference stations are administered by a variety of organizations, including government agencies and public universities, and thus serve a wide range of positioning needs. Despite the diversity of the networks and their intended audiences, a core function of all of the networks is to provide a stable framework for high-precision positioning in support of diverse commercial and scientific applications. In addition, the geographic distribution of stations provides a nation-wide access to the International Terrestrial Reference Frame (ITRF). For real-time kinematic (RTK) and rapid static applications that depend on the pseudo-range observable, the accuracy with which a roaming user may locate their assets with respect to the ITRF may be limited by site-specific multipath. The issue is particularly critical for users depending on pseudorange measurements for "real-time" (or "nearreal-time") kinematic GPS positioning, where ambiguity resolution is a critical step. The pseudorange multipath assessment considered in this research was performed for a total of 53 stations (see Figure 1) that collected continuous GPS data, 24 hours per day, and 365 days of the 


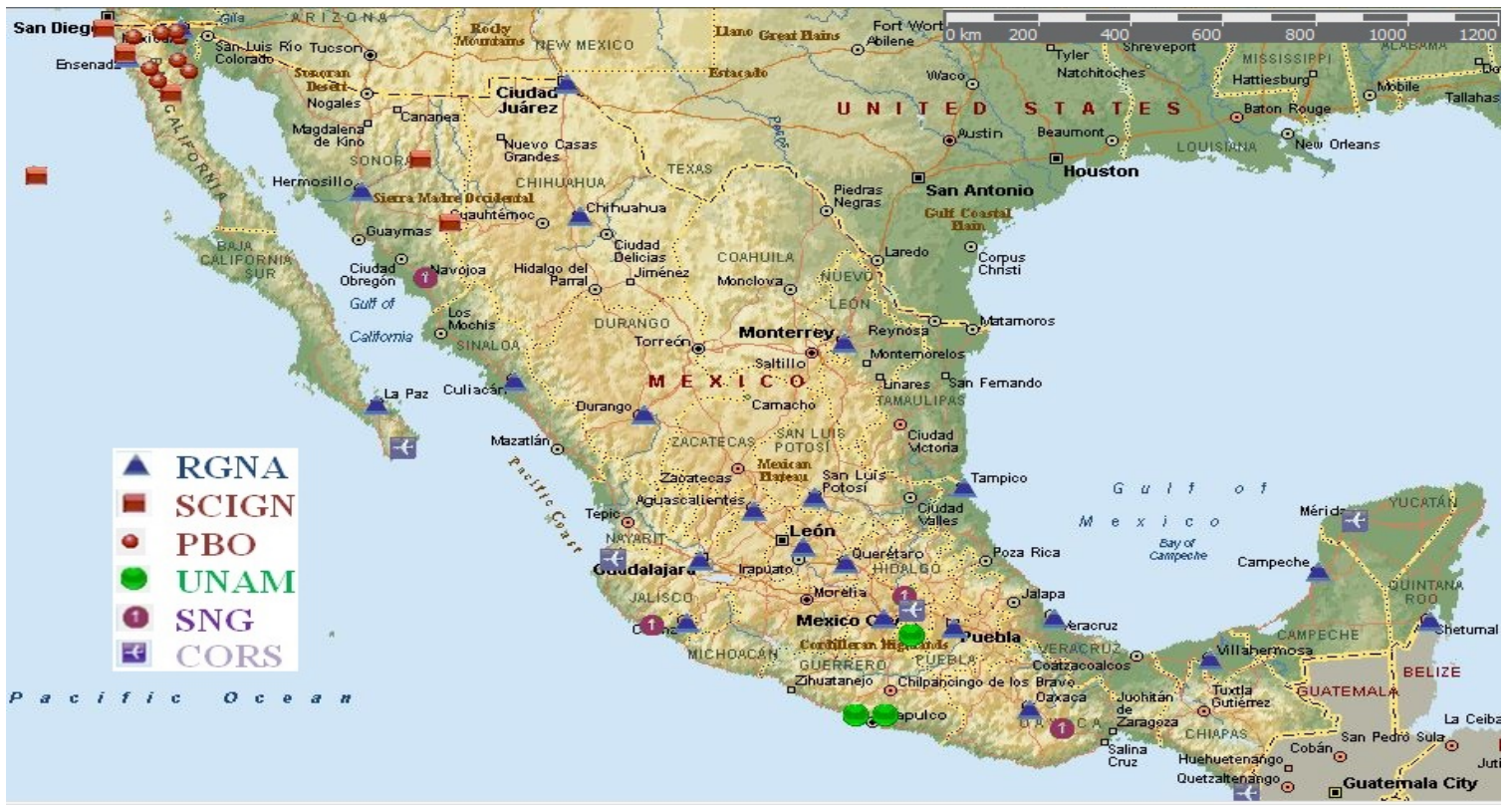

Figure 1. CGPS sites in the Mexican territory (Map-Microsoft Streets \& Trips).

year. We estimated the averaged daily root mean square pseudorange multipath variations (MP1-RMS and MP2RMS) using the TEQC program, described in [3], in order to characterize the performance of each CGPS reference station based on of the level of multipath.

In some cases our analysis of the most severely affected sites was aided by photographs which provided clues regarding the possible sources of pseudorange multipath. We anticipate that our preliminary results will improve understanding of pseudorange multipath errors for reference networks in Mexico. All GPS sites are affected to some extent by multipath effects, which arise when reflected GPS satellite signals reach the receiving antenna, interfering with and obscuring the direct signal used for precise positioning. This effect may vary slowly on a seasonal basis, or abruptly due to natural events such as snowfall. Different research studies of multipath effects and suitable processing techniques can be referred for example by $[1,2,4,5,7,10,12-14]$. These papers show that multipath errors are larger for pseudorange (up to several meters) than for carrier phases (usually, millimeter to centimeter level). Since the multipath effects depend on the satellite geometry and the surrounding environment of the GPS antenna (as well as the antenna type), the effect is practically the same after one sidereal day under similar atmospheric conditions. With the current GPS constellation, the entire satellite configuration repeats each day, advancing only about 4 minutes between two consecutive days. Thus, the positioning solution of data derived from the repetition of the GPS satellite constellation between two sidereal days ought to be affected by "systematic" time-correlated multipath error. In gen- eral, this effect can be used to mitigate the multipath effect from the positioning time-series results $[4,7,13]$ Reference [6] was the first to evaluate the pseudo-range multipath for a great number of CGPS stations from the CORS network, to closely identify problematic sites, and to compare various GPS hardware (i.e., receiver and antenna type) combinations. In addition, multipath may contain valuable information about the local environment. For example, $[8,15]$ had used uncalibrated pseudorange multipath variations (incoming signals are reflected by the ground before reception by the GPS receiver) at a single GPS site in order to investigate soil moisture, snow, and vegetation fluctuations. Therefore, pseud orange multipath estimates may also serve as a source of environmental sensor data.

\section{GPS Instrumentation and Data Availability}

In general, the GPS hardware for the different GPS arrays in Mexico consists of dual-frequency 12-20 channel, geodetic-grade GPS receivers and antennas. However, the brand of GPS receivers used at most of the networks is Trimble 5700, Trimble NETRS and Ashtech-Z12 receivers. The most common GPS antennas are Trimble Zephyr Geodetic (TRM41249.00), Ashtech Geodetic (ASH700228D), Trimble Dorne Margolin

(TRM59800.00) and Ashtech Dorne Margolin

(ASH701945B_M) both with Choke-Ring; these last two types of antennas are usually designed to reduce L1 multipath. Table 1 illustrates the GPS data availability indicated by the number of days available per year for all the sites considered in the experiment, including the site lo- 
Table 1. GPS data availability for CGPS sites in Mexico ( ${ }^{*}$ means these CGPS station have been replaced, ${ }^{* *}$ means that IITJ is a cooperative station of the RGNA and $x$ means no data available for that year).

\begin{tabular}{|c|c|c|c|c|c|c|c|c|c|c|c|c|c|c|c|c|c|c|c|c|c|}
\hline \multirow{2}{*}{ Four Cha. ID } & \multirow{2}{*}{ Site Location } & \multirow{2}{*}{ GPS Array } & \multicolumn{18}{|c|}{ Days of GPS data available per year } & \multirow[b]{2}{*}{12} \\
\hline & & & 94 & 95 & 96 & 97 & 98 & 99 & 00 & 01 & 02 & 03 & 04 & 05 & 06 & 07 & 08 & 09 & 10 & 11 & \\
\hline CHET & Chetumal & RGNA & $\mathrm{x}$ & $\mathrm{X}$ & $\mathrm{x}$ & $\mathrm{X}$ & $\mathrm{X}$ & $\mathrm{x}$ & $\mathrm{x}$ & $\mathrm{x}$ & $\mathrm{x}$ & $\mathrm{x}$ & $\mathrm{x}$ & 87 & 359 & 361 & 366 & 360 & 363 & 362 & 364 \\
\hline CHI3 & Chihuahua & RGNA & $\mathrm{x}$ & $\mathrm{x}$ & $\mathrm{x}$ & $\mathrm{x}$ & $\mathrm{x}$ & $\mathrm{x}$ & $\mathrm{x}$ & $\mathrm{x}$ & $\mathrm{x}$ & $\mathrm{x}$ & $\mathrm{x}$ & $\mathrm{x}$ & $\mathrm{x}$ & $\mathrm{x}$ & $\mathrm{x}$ & $\mathrm{x}$ & 359 & 365 & 363 \\
\hline COL2 & Colima & RGNA & $\mathrm{x}$ & $\mathrm{x}$ & $\mathrm{x}$ & $\mathrm{x}$ & $\mathrm{x}$ & $\mathrm{x}$ & $\mathrm{x}$ & $\mathrm{x}$ & $\mathrm{x}$ & $\mathrm{x}$ & $\mathrm{x}$ & 82 & 352 & 364 & 366 & 364 & 365 & 364 & 365 \\
\hline CULI* & Culiacán & RGNA & $\mathrm{x}$ & 269 & 242 & 286 & 131 & $\mathrm{x}$ & 85 & 261 & 216 & 347 & $\mathrm{x}$ & 364 & 353 & 193 & $\mathrm{x}$ & $\mathrm{X}$ & $\mathrm{X}$ & X & $\mathrm{X}$ \\
\hline CULC & Culiacán & RGNA & $\mathrm{x}$ & $\mathrm{x}$ & $\mathrm{x}$ & $\mathrm{x}$ & $\mathrm{x}$ & $\mathrm{x}$ & $\mathrm{x}$ & $\mathrm{x}$ & $\mathrm{x}$ & $\mathrm{x}$ & $\mathrm{x}$ & $\mathrm{x}$ & $\mathrm{x}$ & $\mathrm{x}$ & $\mathrm{x}$ & $\mathrm{x}$ & 358 & 353 & 363 \\
\hline CAM2* & Campeche & RGNA & $\mathrm{x}$ & $\mathrm{x}$ & $\mathrm{x}$ & $\mathrm{x}$ & $\mathrm{x}$ & $\mathrm{x}$ & $\mathrm{x}$ & $\mathrm{x}$ & $\mathrm{x}$ & $\mathrm{x}$ & $\mathrm{x}$ & 86 & 361 & 359 & 346 & $\mathrm{x}$ & $\mathrm{x}$ & $\mathrm{x}$ & $\mathrm{x}$ \\
\hline ICAM & Campeche & RGNA & $\mathrm{x}$ & $\mathrm{x}$ & $\mathrm{x}$ & $\mathrm{x}$ & $\mathrm{x}$ & $\mathrm{x}$ & $\mathrm{x}$ & $\mathrm{x}$ & $\mathrm{x}$ & $\mathrm{x}$ & $\mathrm{x}$ & $\mathrm{x}$ & $\mathrm{x}$ & $\mathrm{x}$ & $\mathrm{x}$ & $\mathrm{x}$ & 359 & 362 & 365 \\
\hline ICEP & Puebla & RGNA & $\mathrm{x}$ & $\mathrm{x}$ & $\mathrm{x}$ & $\mathrm{x}$ & $\mathrm{x}$ & $\mathrm{x}$ & $\mathrm{x}$ & $\mathrm{x}$ & $\mathrm{x}$ & $\mathrm{x}$ & $\mathrm{x}$ & $\mathrm{x}$ & $\mathrm{x}$ & $\mathrm{x}$ & $\mathrm{x}$ & $\mathrm{x}$ & 343 & 346 & 315 \\
\hline IDGO & Durango & RGNA & $\mathrm{x}$ & $\mathrm{x}$ & $\mathrm{x}$ & $\mathrm{x}$ & $\mathrm{x}$ & $\mathrm{x}$ & $\mathrm{x}$ & $\mathrm{x}$ & $\mathrm{x}$ & $\mathrm{x}$ & $\mathrm{x}$ & $\mathrm{x}$ & X & $\mathrm{X}$ & $\mathrm{x}$ & $\mathrm{x}$ & 355 & 349 & 361 \\
\hline IITJ** & Jalisco & RGNA & $\mathrm{x}$ & $\mathrm{x}$ & $\mathrm{x}$ & $\mathrm{x}$ & $\mathrm{x}$ & $\mathrm{x}$ & $\mathrm{x}$ & $\mathrm{x}$ & $\mathrm{x}$ & $\mathrm{x}$ & 139 & 330 & 361 & 328 & 291 & 356 & 363 & 365 & 365 \\
\hline IMIE & Ensenada & RGNA & $\mathrm{x}$ & $\mathrm{x}$ & $\mathrm{x}$ & $\mathrm{x}$ & $\mathrm{x}$ & $\mathrm{x}$ & $\mathrm{x}$ & $\mathrm{x}$ & $\mathrm{x}$ & $\mathrm{x}$ & $\mathrm{x}$ & $\mathrm{x}$ & $\mathrm{x}$ & $\mathrm{x}$ & $\mathrm{x}$ & $\mathrm{x}$ & $\mathrm{x}$ & $\mathrm{x}$ & 342 \\
\hline INEG & Aguascalientes & RGNA & $\mathrm{x}$ & $\mathrm{x}$ & $\mathrm{x}$ & $\mathrm{x}$ & 282 & 245 & 166 & 305 & 81 & $\mathrm{x}$ & $\mathrm{x}$ & 91 & 353 & 363 & 366 & 361 & 365 & 363 & 363 \\
\hline LPAZ* & La Paz & RGNA & 340 & 336 & 295 & 321 & 344 & 299 & 149 & $\mathrm{x}$ & 254 & 360 & 352 & 364 & 358 & 362 & 364 & 359 & 365 & 365 & $\mathrm{x}$ \\
\hline IPAZ & La Paz & RGNA & $\mathrm{X}$ & $\mathrm{X}$ & $\mathrm{X}$ & $\mathrm{X}$ & $\mathrm{X}$ & $\mathrm{X}$ & X & $\mathrm{x}$ & $\mathrm{X}$ & $\mathrm{X}$ & $\mathrm{x}$ & $\mathrm{x}$ & $\mathrm{x}$ & $\mathrm{x}$ & $\mathrm{x}$ & $\mathrm{x}$ & $\mathrm{x}$ & $\mathrm{x}$ & 346 \\
\hline MERI & Mérida & RGNA & $\mathrm{x}$ & $\mathrm{x}$ & $\mathrm{x}$ & $\mathrm{x}$ & $\mathrm{x}$ & $\mathrm{x}$ & $\mathrm{x}$ & $\mathrm{x}$ & $\mathrm{x}$ & $\mathrm{x}$ & $\mathrm{x}$ & 90 & 362 & 364 & 365 & 362 & 364 & 365 & 365 \\
\hline MEXI & Mexicali & RGNA & 198 & 274 & 264 & $\mathrm{x}$ & 321 & 235 & 277 & 338 & 200 & 226 & 210 & 361 & 347 & 363 & 366 & 364 & 358 & 365 & 365 \\
\hline MTY2 & Monterrey & RGNA & $\mathrm{x}$ & $\mathrm{x}$ & $\mathrm{X}$ & $\mathrm{x}$ & $\mathrm{x}$ & $\mathrm{X}$ & $\mathrm{X}$ & $\mathrm{x}$ & $\mathrm{x}$ & $\mathrm{x}$ & $\mathrm{x}$ & 91 & 355 & 364 & 365 & 357 & 365 & 365 & 365 \\
\hline OAX2 & Oaxaca & RGNA & $\mathrm{x}$ & $\mathrm{x}$ & $\mathrm{x}$ & $\mathrm{x}$ & $x$ & $\mathrm{x}$ & $\mathrm{x}$ & $\mathrm{x}$ & $\mathrm{x}$ & $\mathrm{x}$ & $\mathrm{x}$ & 99 & 361 & 365 & 364 & 348 & 365 & 362 & 365 \\
\hline TAMP & Tampico & RGNA & $\mathrm{x}$ & $\mathrm{x}$ & $\mathrm{x}$ & $\mathrm{x}$ & $\mathrm{x}$ & $\mathrm{x}$ & $\mathrm{x}$ & $\mathrm{x}$ & $\mathrm{x}$ & $\mathrm{x}$ & $\mathrm{x}$ & $\mathrm{x}$ & $\mathrm{x}$ & X & $\mathrm{x}$ & $\mathrm{x}$ & 339 & 350 & 360 \\
\hline TOL2 & Toluca & RGNA & $\mathrm{x}$ & $\mathrm{x}$ & $\mathrm{x}$ & $\mathrm{x}$ & $\mathrm{x}$ & $\mathrm{x}$ & $\mathrm{x}$ & $\mathrm{x}$ & $\mathrm{x}$ & $\mathrm{x}$ & $\mathrm{x}$ & 89 & 345 & 361 & 364 & 363 & 363 & 365 & 362 \\
\hline UGTO & Guanajuato & RGNA & $\mathrm{x}$ & $\mathrm{x}$ & $\mathrm{x}$ & $\mathrm{x}$ & $\mathrm{x}$ & $\mathrm{x}$ & $\mathrm{x}$ & $\mathrm{x}$ & $\mathrm{x}$ & $\mathrm{X}$ & $\mathrm{x}$ & $\mathrm{X}$ & $\mathrm{x}$ & $\mathrm{X}$ & $\mathrm{x}$ & $\mathrm{x}$ & 340 & 360 & 363 \\
\hline UQRO & Querétaro & RGNA & $\mathrm{X}$ & $\mathrm{X}$ & $\mathrm{X}$ & $\mathrm{x}$ & $\mathrm{x}$ & $\mathrm{x}$ & $\mathrm{x}$ & $\mathrm{X}$ & $\mathrm{X}$ & $\mathrm{x}$ & $\mathrm{x}$ & $\mathrm{x}$ & $\mathrm{X}$ & $\mathrm{x}$ & $\mathrm{x}$ & $\mathrm{x}$ & $\mathrm{x}$ & 351 & 360 \\
\hline USLP & S. Luis Potosí & RGNA & $\mathrm{x}$ & $\mathrm{x}$ & $\mathrm{X}$ & $\mathrm{x}$ & $\mathrm{X}$ & $\mathrm{x}$ & $\mathrm{X}$ & $\mathrm{X}$ & $\mathrm{x}$ & $\mathrm{x}$ & $\mathrm{x}$ & $\mathrm{X}$ & $\mathrm{x}$ & $\mathrm{x}$ & $\mathrm{X}$ & $\mathrm{x}$ & 327 & 352 & 363 \\
\hline UVER & Veracruz & RGNA & $\mathrm{x}$ & $\mathrm{x}$ & $\mathrm{x}$ & $\mathrm{x}$ & $\mathrm{x}$ & $\mathrm{x}$ & $\mathrm{x}$ & $\mathrm{x}$ & $\mathrm{x}$ & $\mathrm{x}$ & $\mathrm{x}$ & $\mathrm{x}$ & $\mathrm{x}$ & $\mathrm{x}$ & $\mathrm{x}$ & $\mathrm{x}$ & $\mathrm{X}$ & $\mathrm{x}$ & 229 \\
\hline PHJX & Cucapah & PBO & $\mathrm{x}$ & $\mathrm{x}$ & $\mathrm{x}$ & $\mathrm{x}$ & $\mathrm{x}$ & $\mathrm{x}$ & $\mathrm{x}$ & $\mathrm{x}$ & $\mathrm{x}$ & $\mathrm{x}$ & $\mathrm{x}$ & $\mathrm{x}$ & $\mathrm{x}$ & $\mathrm{x}$ & $\mathrm{x}$ & $\mathrm{x}$ & $\mathrm{x}$ & 63 & 365 \\
\hline PJZX & Sr. Juárez & PBO & $\mathrm{x}$ & $\mathrm{x}$ & $\mathrm{x}$ & $\mathrm{x}$ & $\mathrm{x}$ & $\mathrm{x}$ & $\mathrm{x}$ & $\mathrm{x}$ & $\mathrm{x}$ & $\mathrm{x}$ & $\mathrm{x}$ & $\mathrm{x}$ & $\mathrm{x}$ & $\mathrm{x}$ & $\mathrm{x}$ & $\mathrm{x}$ & $\mathrm{x}$ & 323 & 363 \\
\hline PLPX & Las Pintas & PBO & $\mathrm{x}$ & $\mathrm{x}$ & $\mathrm{x}$ & $\mathrm{x}$ & $\mathrm{x}$ & $\mathrm{x}$ & $\mathrm{x}$ & $\mathrm{x}$ & $\mathrm{x}$ & $\mathrm{x}$ & $\mathrm{x}$ & $\mathrm{x}$ & $\mathrm{x}$ & $\mathrm{x}$ & $\mathrm{x}$ & $\mathrm{x}$ & $\mathrm{x}$ & 363 & 365 \\
\hline PLTX & Las Tinajas & $\mathrm{PBO}$ & $\mathrm{x}$ & $\mathrm{x}$ & $\mathrm{x}$ & $\mathrm{x}$ & $\mathrm{x}$ & $\mathrm{x}$ & $\mathrm{x}$ & $\mathrm{x}$ & $\mathrm{x}$ & $\mathrm{x}$ & $\mathrm{x}$ & $\mathrm{x}$ & $\mathrm{x}$ & $\mathrm{x}$ & $\mathrm{x}$ & $\mathrm{x}$ & $\mathrm{x}$ & 364 & 365 \\
\hline PSTX & San Isidoro & PBO & $\mathrm{x}$ & $\mathrm{x}$ & $\mathrm{x}$ & $\mathrm{x}$ & $\mathrm{x}$ & $\mathrm{x}$ & $\mathrm{x}$ & $\mathrm{x}$ & $\mathrm{x}$ & $\mathrm{x}$ & $\mathrm{x}$ & $\mathrm{x}$ & $\mathrm{x}$ & $\mathrm{x}$ & $\mathrm{x}$ & $\mathrm{x}$ & $\mathrm{x}$ & 364 & 364 \\
\hline PTAX & Puerta Peak & PBO & $\mathrm{x}$ & $\mathrm{x}$ & $\mathrm{x}$ & $\mathrm{x}$ & $\mathrm{x}$ & $\mathrm{x}$ & $\mathrm{x}$ & $\mathrm{x}$ & $\mathrm{x}$ & $\mathrm{x}$ & $\mathrm{x}$ & $\mathrm{x}$ & $\mathrm{x}$ & $\mathrm{x}$ & $\mathrm{x}$ & $\mathrm{x}$ & $\mathrm{x}$ & 244 & 365 \\
\hline PTEX & Testerazo & PBO & $\mathrm{x}$ & $\mathrm{x}$ & $\mathrm{x}$ & $\mathrm{x}$ & $\mathrm{x}$ & $\mathrm{x}$ & $\mathrm{x}$ & $\mathrm{x}$ & $\mathrm{x}$ & $\mathrm{x}$ & $\mathrm{X}$ & $\mathrm{X}$ & $\mathrm{X}$ & $\mathrm{X}$ & $\mathrm{X}$ & $\mathrm{x}$ & $\mathrm{x}$ & 248 & 364 \\
\hline SG21 & Teoloyucan & SNG & $\mathrm{x}$ & $\mathrm{x}$ & $\mathrm{x}$ & $\mathrm{x}$ & $\mathrm{x}$ & $\mathrm{x}$ & $\mathrm{x}$ & $\mathrm{x}$ & $\mathrm{x}$ & $\mathrm{x}$ & 229 & 295 & 337 & 178 & 32 & $\mathrm{x}$ & $\mathrm{x}$ & $\mathrm{X}$ & $\mathrm{X}$ \\
\hline OXEC & El Camarón & SNG & $\mathrm{x}$ & $\mathrm{X}$ & $\mathrm{X}$ & $\mathrm{x}$ & $\mathrm{X}$ & $\mathrm{x}$ & $\mathrm{X}$ & $\mathrm{x}$ & $\mathrm{X}$ & $\mathrm{x}$ & $\mathrm{x}$ & $\mathrm{X}$ & $\mathrm{X}$ & 347 & 151 & $\mathrm{x}$ & $\mathrm{X}$ & $\mathrm{X}$ & $\mathrm{X}$ \\
\hline UCOM & Manzanillo & SNG & $\mathrm{x}$ & $\mathrm{x}$ & $\mathrm{x}$ & $\mathrm{x}$ & $\mathrm{x}$ & $\mathrm{x}$ & $\mathrm{x}$ & $\mathrm{x}$ & $\mathrm{x}$ & $\mathrm{x}$ & $\mathrm{x}$ & $\mathrm{x}$ & $\mathrm{x}$ & 326 & 134 & $\mathrm{x}$ & $\mathrm{x}$ & $\mathrm{x}$ & $\mathrm{x}$ \\
\hline SA61 & Navojoa & SNG & $\mathrm{x}$ & $\mathrm{x}$ & $\mathrm{x}$ & $\mathrm{x}$ & $\mathrm{x}$ & $\mathrm{x}$ & $\mathrm{x}$ & $\mathrm{x}$ & $\mathrm{x}$ & $\mathrm{x}$ & $\mathrm{x}$ & $\mathrm{x}$ & $\mathrm{x}$ & $\mathrm{X}$ & $\mathrm{x}$ & 18 & 361 & 258 & $\mathrm{x}$ \\
\hline CIC1 & Cicese & SCIGN & $\mathrm{x}$ & $\mathrm{x}$ & $\mathrm{x}$ & $\mathrm{x}$ & $\mathrm{x}$ & $\mathrm{x}$ & $\mathrm{x}$ & $\mathrm{x}$ & $\mathrm{x}$ & $\mathrm{x}$ & $\mathrm{x}$ & $\mathrm{x}$ & 25 & 353 & 359 & 346 & $\mathrm{x}$ & $\mathrm{x}$ & $\mathrm{x}$ \\
\hline SPMX & S. P. Mártir & SCIGN & $\mathrm{x}$ & $\mathrm{x}$ & $\mathrm{x}$ & $\mathrm{x}$ & $\mathrm{x}$ & $\mathrm{x}$ & $\mathrm{x}$ & $\mathrm{x}$ & $\mathrm{x}$ & $\mathrm{x}$ & $\mathrm{x}$ & $\mathrm{X}$ & $\mathrm{x}$ & $\mathrm{X}$ & $\mathrm{x}$ & 216 & $\mathrm{x}$ & $\mathrm{x}$ & $\mathrm{x}$ \\
\hline USMX & U. de la Sierra & SCIGN & $\mathrm{x}$ & $\mathrm{x}$ & $\mathrm{x}$ & $\mathrm{x}$ & $\mathrm{x}$ & $\mathrm{x}$ & $\mathrm{x}$ & $\mathrm{x}$ & $\mathrm{x}$ & $\mathrm{x}$ & $\mathrm{x}$ & 327 & 347 & 363 & 365 & 66 & $\mathrm{x}$ & $\mathrm{x}$ & $x$ \\
\hline YESX & Yecora & SCIGN & $\mathrm{x}$ & $\mathrm{x}$ & $\mathrm{x}$ & $\mathrm{x}$ & $\mathrm{x}$ & $\mathrm{x}$ & $\mathrm{x}$ & $\mathrm{x}$ & $\mathrm{x}$ & $\mathrm{x}$ & $\mathrm{x}$ & $\mathrm{x}$ & $\mathrm{x}$ & $\mathrm{x}$ & $\mathrm{x}$ & $\mathrm{x}$ & $\mathrm{x}$ & 181 & $\mathrm{x}$ \\
\hline GUAX & Isla Gpe. & SCIGN & $\mathrm{x}$ & $\mathrm{x}$ & $\mathrm{x}$ & $\mathrm{x}$ & $\mathrm{x}$ & $\mathrm{x}$ & $\mathrm{X}$ & $\mathrm{x}$ & 344 & 179 & 360 & 90 & $\mathrm{x}$ & $\mathrm{x}$ & $x$ & $\mathrm{x}$ & $\mathrm{x}$ & $\mathrm{x}$ & $\mathrm{x}$ \\
\hline CORX & Cors. Island & SCIGN & $\mathrm{x}$ & $\mathrm{x}$ & $\mathrm{x}$ & $\mathrm{x}$ & $\mathrm{x}$ & $\mathrm{x}$ & 38 & 310 & 356 & 159 & 363 & 161 & $\mathrm{x}$ & $\mathrm{x}$ & $\mathrm{x}$ & $\mathrm{x}$ & $\mathrm{x}$ & $\mathrm{x}$ & $\mathrm{x}$ \\
\hline DOAR & Dos Arroyos & UNAM & $\mathrm{x}$ & $\mathrm{x}$ & $\mathrm{x}$ & $\mathrm{X}$ & $\mathrm{x}$ & $\mathrm{x}$ & $\mathrm{X}$ & $\mathrm{x}$ & $\mathrm{x}$ & 284 & 365 & 291 & 280 & 65 & 91 & 59 & $\mathrm{x}$ & $\mathrm{x}$ & $\mathrm{x}$ \\
\hline CAYA & Cayaco & UNAM & $\mathrm{x}$ & $\mathrm{x}$ & $\mathrm{x}$ & 318 & 289 & 332 & 342 & 260 & 263 & 292 & 41 & $\mathrm{X}$ & $\mathrm{x}$ & $\mathrm{x}$ & $\mathrm{x}$ & $\mathrm{x}$ & $\mathrm{x}$ & $\mathrm{x}$ & $\mathrm{x}$ \\
\hline YAIG & Yautepec & UNAM & $\mathrm{x}$ & $\mathrm{x}$ & $\mathrm{x}$ & $\mathrm{X}$ & $\mathrm{X}$ & 182 & 245 & 216 & 151 & 243 & 144 & $\mathrm{x}$ & $\mathrm{x}$ & $\mathrm{x}$ & $\mathrm{X}$ & $\mathrm{x}$ & $\mathrm{x}$ & $\mathrm{X}$ & $\mathrm{X}$ \\
\hline MMD1 & Mérida & CORS & $\mathrm{x}$ & $\mathrm{x}$ & $\mathrm{x}$ & $\mathrm{x}$ & $\mathrm{x}$ & $\mathrm{X}$ & $\mathrm{X}$ & $\mathrm{x}$ & $\mathrm{X}$ & $\mathrm{x}$ & $\mathrm{X}$ & $\mathrm{x}$ & $\mathrm{x}$ & $\mathrm{x}$ & 213 & 357 & 363 & 362 & 360 \\
\hline MMX1 & México D.F. & CORS & $\mathrm{x}$ & $\mathrm{x}$ & $\mathrm{x}$ & $\mathrm{x}$ & $\mathrm{x}$ & $\mathrm{x}$ & $\mathrm{x}$ & $\mathrm{x}$ & $\mathrm{x}$ & $\mathrm{x}$ & $\mathrm{x}$ & $\mathrm{x}$ & $\mathrm{x}$ & $\mathrm{x}$ & 207 & 354 & 363 & 364 & 351 \\
\hline MPR1 & P. Vallarta & CORS & $\mathrm{X}$ & $\mathrm{X}$ & $\mathrm{X}$ & $\mathrm{x}$ & $\mathrm{x}$ & $\mathrm{x}$ & $\mathrm{X}$ & $\mathrm{x}$ & $\mathrm{x}$ & $\mathrm{x}$ & $\mathrm{X}$ & $\mathrm{x}$ & $\mathrm{x}$ & $\mathrm{x}$ & 212 & 356 & 363 & 364 & 357 \\
\hline MSD1 & S. J. del Cabo & CORS & $\mathrm{x}$ & $\mathrm{x}$ & $\mathrm{x}$ & $\mathrm{x}$ & $\mathrm{x}$ & $\mathrm{x}$ & $\mathrm{x}$ & $\mathrm{x}$ & $\mathrm{x}$ & $\mathrm{x}$ & $\mathrm{x}$ & $\mathrm{x}$ & $\mathrm{x}$ & $\mathrm{x}$ & 211 & 323 & 365 & 364 & 360 \\
\hline MTP1 & Tapachula & CORS & $\mathrm{X}$ & $\mathrm{x}$ & $\mathrm{x}$ & $\mathrm{x}$ & $\mathrm{x}$ & $\mathrm{x}$ & $\mathrm{x}$ & $\mathrm{x}$ & $\mathrm{x}$ & $\mathrm{x}$ & $\mathrm{x}$ & $\mathrm{x}$ & $\mathrm{x}$ & $\mathrm{X}$ & 213 & 356 & 198 & 220 & 361 \\
\hline
\end{tabular}


cation and the GPS array they belong. Two sites of the RGNA network (LPAZ and MEXI) recorded data continuously since 1994. Of these two stations, only MEXI continues recording data up to date. LPAZ was replaced by the station IPAZ in 2012. Nine additional sites from the RGNA network (CHET, COL2, HER2, IITJ, INEG, MERI, MTY2, OAX2 and TOL2) recorded data continuously for eight to thirteen years and the remaining RGNA sites have recorded data for only one to four years. Sites that belong to PBO network (PALX, PHJX, PJZX, PLPX, PLTX, PSTX, PTAX and PTEX) recorded data for two to three years. There exist six sites (CIC1, CORX, GUAX, SPMX, USMX and YESX) that belong to the SCIGN network and three sites from the SNG array (OXEC, SA61 and UCOM) that recorded between one and six years of continuous data, but these sites are no longer operational. There are three sites (DOAR, CAYA and YAIG) from UNAM and another site (SG21) from SNG that recorded data for some periods between 1997 and 2009, but there are no data after 2009. Finally, there are five sites (MMD1, MMX1, MPR1, MSD1 and MTP1) from the FAA CORS in Mexico, which recorded continuous data from 2008.

\section{Pseudorange Multipath Assessment}

We used the TEQC software (Test of Quality Check) provided by UNAVCO, which based on linear combinations of the pseudo-range and carrier phase observations seems to be the best option for estimating the pseudorange multipath effect [3] and [6]. TEQC software is available for public use at [18] to estimate the daily root mean squared multipath variations for each of the 53 analyzed sites. The main specifications for the GPS data processing included the use of a 30-sec sampling rate and $10^{\circ}$ elevation cut-off angle. In addition, we followed the pseudorange multipath approach described in [3,6,1619]. According to this approach, the inter-channel bias and the non-integer initial phase terms for the GPS satellite and the receiver were not accounted for in the one-way observation equations used for the multipath estimation. It is well known that the pseudorange and carrier phase measurements on $L 1$ and $L 2$ for a satellite $k$ and a receiver $i$ are given by:

$$
\begin{array}{r}
P_{L 1}=R+c\left[\Delta t^{k}-\Delta t_{i}\right]+I_{L 1}+T+M P_{P 1} \\
P_{L 2}=R+c\left[\Delta t^{k}-\Delta t_{i}\right]+I_{L 2}+T+M P_{P 2} \\
\Phi_{L 1}=R+c\left[\Delta t^{k}-\Delta t_{i}\right]+\lambda_{L 1} N_{L 1}-I_{L 1}+T+M P_{\Phi_{L 1}} \\
\Phi_{L 2}=R+c\left[\Delta t^{k}-\Delta t_{i}\right]+\lambda_{L 2} N_{L 2}-I_{L 2}+T+M P_{\Phi_{L 2}}
\end{array}
$$

where: $P_{L 1}$ and $P_{L 2}$ : pseudorange observations (in units of $\mathrm{m}), R$ : geometric distance between the satel- lite and the receiver $(\mathrm{m}), c=300,000$ : constant speed of light $\left(\mathrm{km} \cdot \mathrm{s}^{-1}\right), \Delta t^{k}$ : satellite clock correction $(\mathrm{s})$, $\Delta t_{i}$ : receiver clock correction $(\mathrm{s}), I_{L 1}$ and $I_{L 2}$ : ionospheric range errors $(\mathrm{m}), T$ : tropospheric range error (m), $N_{L 1}$ and $N_{L 2}$ : integer ambiguities (cycles), $M P_{P 1}, M P_{P 2}, M P_{\Phi_{L 1}}$ and $M P_{\Phi_{L 2}}$ : pseudorange and carrier phase multipath, respectively (including the observational noise), $\lambda_{\mathrm{L} 1} \approx 19$ and $\lambda_{\mathrm{L} 2} \approx 24$ : wavelengths of the signals on $L 1$ and $L 2 \quad(\mathrm{~cm})$, $f_{1} \approx 1.5754$ and $f_{2} \approx 1.2276$ : frequencies of signals $L 1$ and $L 2(\mathrm{GHz})$, respectively.

Taking advantage of the relationship between the ionospheric delay for $L 1$ and $L 2$ leads to:

With: $\alpha=\left(f_{1} / f_{2}\right)^{2}$

$$
I_{L 2}=\alpha \cdot I_{L 1}
$$

Subtracting (4) from (3) gives:

$\Phi_{L 1}-\Phi_{L 2}=\lambda_{L 1} N_{L 1}-I_{L 1}+M P_{\Phi_{L 1}}-\lambda_{L 2} N_{L 2}+I_{L 2}-M P_{\Phi_{L 2}}$

Substituting (5) into (6), grouping and simplifying yields:

$\frac{\Phi_{L 1}-\Phi_{L 2}}{[\alpha-1]}=I_{L 1}+\frac{\lambda_{L 1} N_{L 1}-\lambda_{L 2} N_{L 2}}{[\alpha-1]}+\frac{M P_{\Phi_{L 1}}-M P_{\Phi_{L 2}}}{[\alpha-1]}$

Combining (7) with (3) to eliminate $I_{L 1}$ term, results in:

$$
\begin{aligned}
& \Phi_{L 1}+\frac{\Phi_{L 1}-\Phi_{L 2}}{[\alpha-1]} \\
& =R+c\left[\Delta t^{S}-\Delta t_{R}\right]+T+\lambda_{L 1} N_{L 1} \\
& \quad+\frac{\lambda_{L 1} N_{L 1}-\lambda_{L 2} N_{L 2}}{[\alpha-1]}+M P_{\Phi_{L 1}}+\frac{M P_{\Phi_{L 1}}-M P_{\Phi_{L 2}}}{[\alpha-1]} \\
& =R+c\left[\Delta t^{S}-\Delta t_{R}\right]+T+b_{1}+m_{\Phi_{1}}
\end{aligned}
$$

Equation (8) is a linear combination of observed $L 1$ and $L 2$ carrier phases, where the ambiguity bias term $b_{1}$ is introduced as:

$$
b_{1}=\lambda_{L 1} N_{L 1}+\frac{\lambda_{L 1} N_{L 1}-\lambda_{L 2} N_{L 2}}{[\alpha-1]}
$$

While the phase multipath effect is now defined by:

$$
m_{\Phi_{1}}=M P_{\Phi_{L 1}}+\frac{M P_{\Phi_{L 1}}-M P_{\Phi_{L 2}}}{[\alpha-1]}
$$

Combining (3), (7) and (8) gives:

$$
\begin{aligned}
& P_{L 1}-\left(1+\frac{2}{[\alpha-1]}\right) \Phi_{L 1}+\left(\frac{2}{[\alpha-1]}\right) \Phi_{L 2} \\
& =M P_{P 1}-\frac{\lambda_{L 1} N_{L 1}-\lambda_{L 2} N_{L 2}}{[\alpha-1]}-b_{1}+M P_{\Phi_{L 1}}-2 m_{\Phi_{1}}
\end{aligned}
$$


The new ambiguity bias term is now defined by:

$$
\begin{aligned}
B_{1} & =-\frac{\lambda_{L 1} N_{L 1}-\lambda_{L 2} N_{L 2}}{[\alpha-1]}-b_{1} \\
& =-\left(1+\frac{2}{[\alpha-1]}\right) \lambda_{L 1} N_{L 1}+\left(\frac{2}{[\alpha-1]}\right) \lambda_{L 2} N_{L 2}
\end{aligned}
$$

And the new phase multipath effect is introduced as:

$$
\begin{aligned}
M_{\Phi 1} & =-\left[M P_{\Phi_{L 1}}-M P_{\Phi_{L 2}}\right]-m_{\Phi_{1}} \\
& =-\left(1+\frac{2}{[\alpha-1]}\right) M P_{\Phi_{L 1}}+\left(\frac{2}{[\alpha-1]}\right) M P_{\Phi_{L 2}} \\
& =M P_{\Phi_{L 1}}-2 m_{\Phi_{1}}
\end{aligned}
$$

The pseudorange multipath $M P_{1}$ is then expressed as the linear combination from (11), namely:

$$
\begin{aligned}
M P_{1} & =P_{L 1}-\left(1+\frac{2}{[\alpha-1]}\right) \Phi_{L 1}+\left(\frac{2}{[\alpha-1]}\right) \Phi_{L 2} \\
& =M P_{P 1}+B_{1}+M_{\Phi_{1}}
\end{aligned}
$$

Similar derivations are performed to express $M P_{2}$ as a linear combination:

$$
\begin{aligned}
M P_{2} & =P_{L 2}-\left(\frac{2 \cdot \alpha}{[\alpha-1]}\right) \Phi_{L 1}+\left(\frac{2 \cdot \alpha}{[\alpha-1]}-1\right) \Phi_{L 2} \\
& =M P_{P 2}+B_{2}+M_{\Phi 2}
\end{aligned}
$$

with $M P_{P 2}, B_{2}$, and $M_{\Phi 2}$ are defined similarly to $M P_{P 1}, B_{1}$, and $M_{\Phi 1}$.

As mentioned before, multipath error in the pseudoranges is significantly larger (up to several meters) but unbiased, compared to carrier phases (millimeter to centimeter level) which are biased. Also, both types of GPS measurements are sensitive to the effects of the troposphere, ionosphere, satellite orbits, receiver position, and clocks. Thus, (14) removes all of these effects except for the carrier phase bias $\left(B_{1}\right)$, which is a constant, leaving one systematic error term. Random variations in (14) can be reduced by averaging $M P_{P 1}$ values for many satellites. Based on the above derivations, the averaged daily root mean square (MP1-RMS and MP2-RMS) were computed by means of (14) and (15) for all possible tracked satellites during each day at each GPS site included in the experiment.

\section{Results and Analysis}

At present the RGNA network consists of 23 continuous GPS stations administered by INEGI plus one cooperative station, which is controlled by the Institute of Land Information from Jalisco (IITJ). We analyzed the pseudorange multipath for only 27 of the RGNA stations: 24 existing plus three decommissioned sites (CULI, CAM2 and LPAZ). The first RGNA station that we investigated is the INEG site since it had experienced important changes of receiver and antenna type as well as receiver firmware upgrades. Furthermore, INEG is the only site that currently uses a Trimble choke ring antenna (see Figure 2). The first upgrade for the Ashtech Z12 receiver at this site occurred on August 21, 1999 [21]. Then, a change of receiver and antenna happened in February 2000 when the Ashtech Z12 was replaced by a Trimble 4700 receiver and the ASH700228A antenna was replaced by a TRM29659.00 antenna. Another swap of receivers took place in the middle of March, 2008, when the Trimble 4700 was replaced by the Trimble 5700 receiver, which continues recording data up to present. The antenna is mounted on a concrete pillar monument (Figure 2), which is a known source of pseudorange multipath e.g., [2]. Figure 3 shows the evolution of GPS pseudorange multipath at INEG station. GPS hardware replacements at INEG's site clearly impact the pseudorange multipath estimates. Here, two significant improvements can be observed in the multipath results, one at the beginning of 2000 (receiver and antenna replacement) and the other one after mid-march 2008 (receiver replacement). That is, an evident drop of the MP1-RMS decreasing their values abruptly from 80 to $20 \mathrm{~cm}$ and

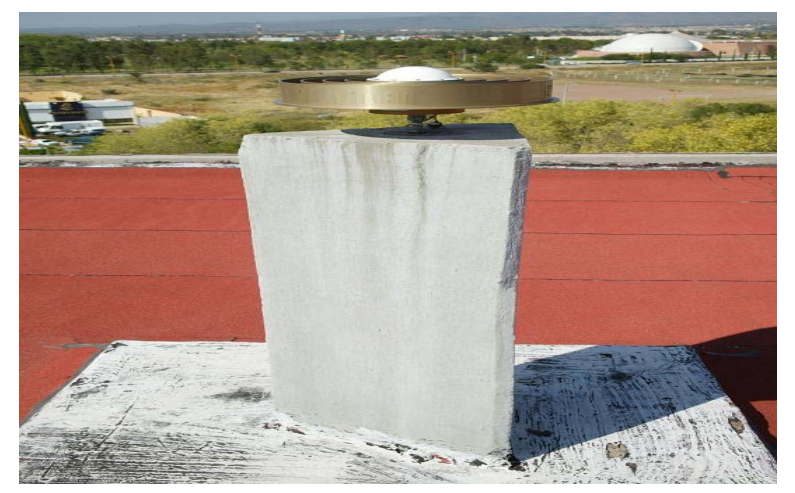

Figure 2. Aguascalientes (INEG) station with choke-ring antenna, RGNA network. Date of photo February, 2000.

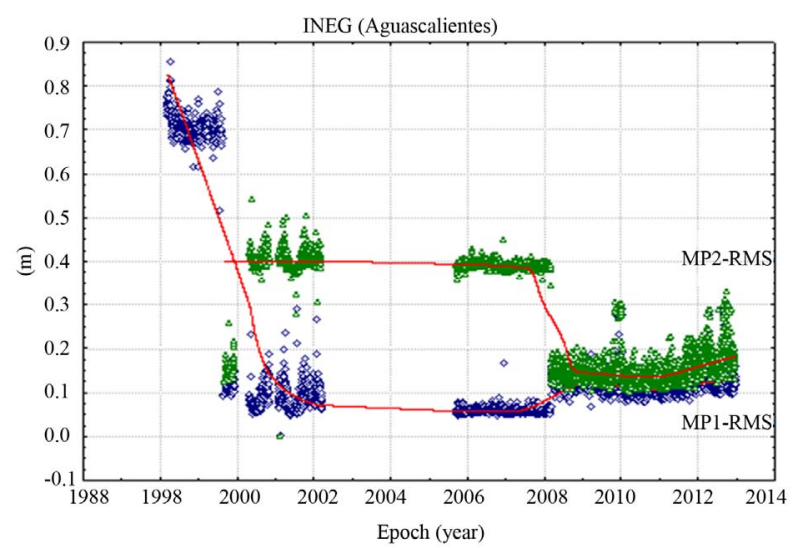

Figure 3. Pseudorange multipath (MP1-RMS and MP2RMS) variations at site INEG, RGNA network. 
also for the MP2-RMS from 50 to $20 \mathrm{~cm}$, respectively. Additionally, there is no solution for the MP2-RMS before September 1999, since INEGI's receiver only recorded C/A code, which was used to generate the MP1RMS.

Figure 4 illustrates the pseudorange multipath (MP1RMS and MP2-RMS) in terms of time-series for the three most contaminated (MEXI, CULI and LPAZ) and the three least affected (IPAZ, UVER and UGTO) RGNA sites. Large multipath RMS is evident in Figures 4(a)-(c), where MP1-RMS values reach up to the meter level ( $\sim 3 \mathrm{~m})$, before 2000. Even though there were some upgrades to the receiver's firmware versions on August 1999 at MEXI and LPAZ and on September 2000 at CULI, only a solution for the MP1-RMS can be reported. Similarly to the data from site INEG, no P1 and P2 observables were available prior to 2000; however, the MP1-RMS results were generated based on the only available C/A code. These higher values of the MP1RMS are likely attributable to the fact that the reported

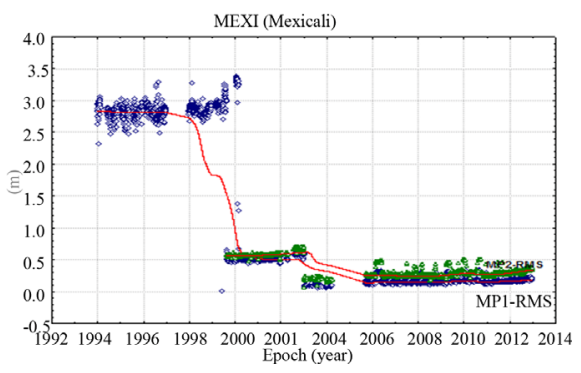

(a)

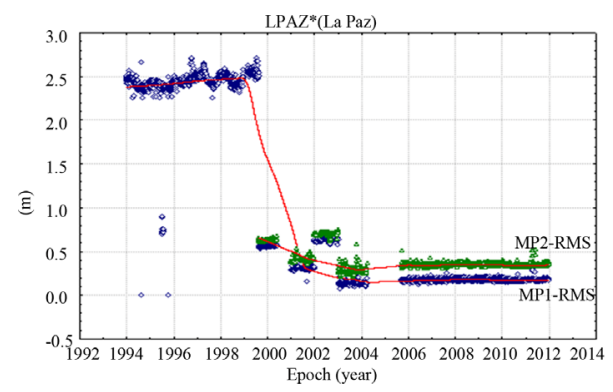

(c)

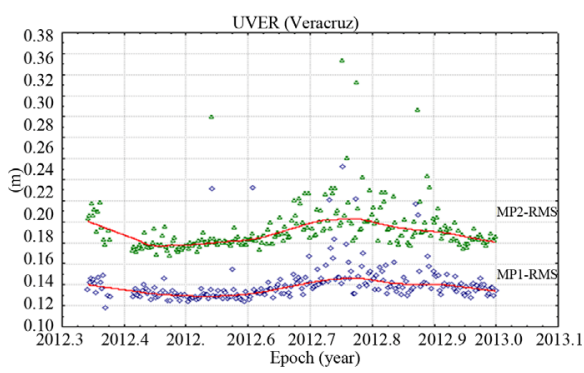

(e)
C/A code is less accurate than the P1 code and possibly due to the receiver upgrades performed at that time. In addition, there was a change of receivers (Ashtech Z12 to a TRIMBLE 5700) and antennas (ASH700228A to a TRM41249.00) in January 2003 at MEXI, CULI and LPAZ stations, which might contribute to the observed drop in multipath RMS of about $50 \mathrm{~cm}$. On the other hand, the less affected sites shown in Figures 4(d)-(f) ranged within 10 to $40 \mathrm{~cm}$ on both MP1-RMS and MP2-RMS variations. For the RGNA network, the most affected station on the MP1-RMS was MEXI, while the most affected on the MP2-RMS was site IITJ that uses an older TRIMBLE 4400 GPS receiver and a TRM23903.00 antenna, which never has been replaced since the installation of this site. It should be indicated that the three less affected sites from the RGNA use a modern Trimble Zephyr Geodetic rather than a Choke-Ring antenna (typically designed to mitigate L1 multipath). Panoramic photographs (taken in January 2003) of the three most affected RGNA sites are presented in Figure 5 [21]; here

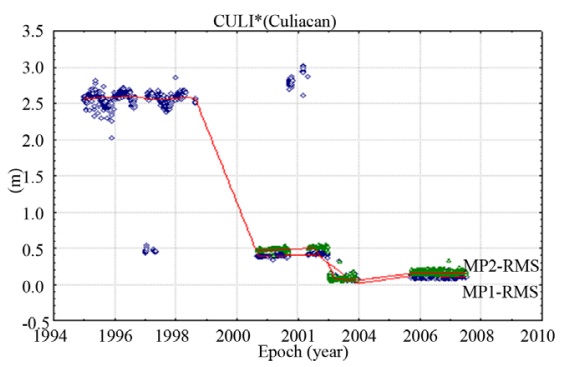

(b)

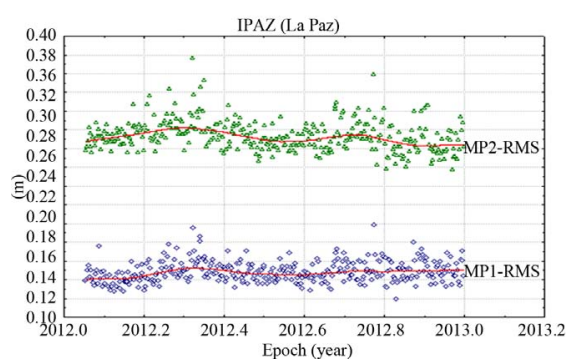

(d)

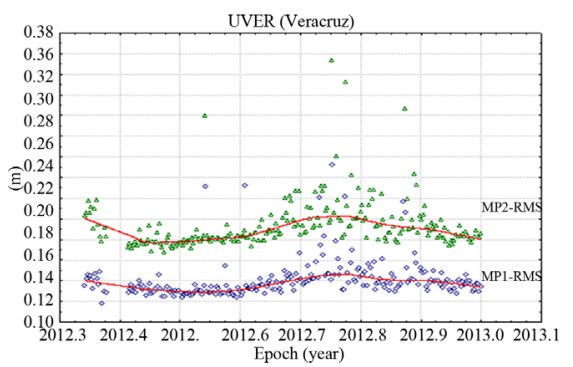

(f)

Figure 4. Pseudorange multipath MP1-RMS and MP2-RMS variations, most affected sites: (a) Mexicali (MEXI); (b) Culiacan (CULI); (c) La Paz (LPAZ) and least affected sites: (d) La Paz (IPAZ); (e) Veracruz (UVER); (f) Guanajuato (UGTO), RGNA network. 


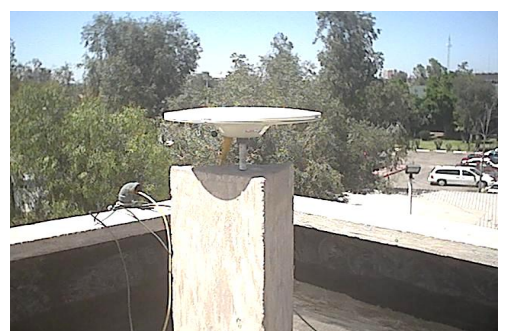

(a)

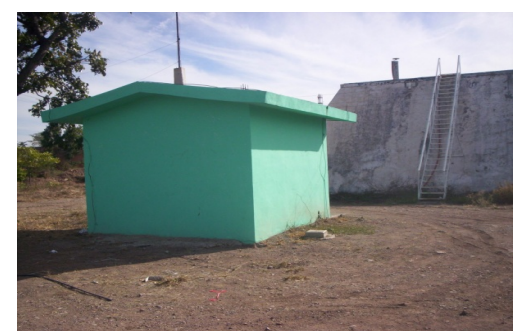

(b)

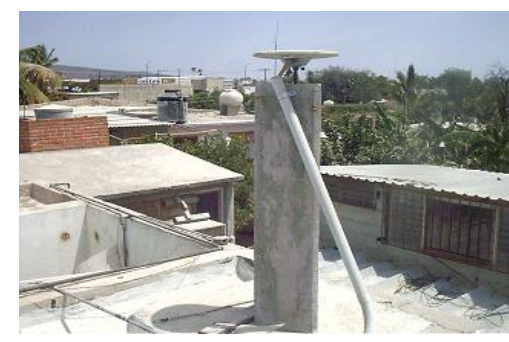

(c)

Figure 5. RGNA network sites: (a) Mexicali (MEXI), (b) Culiacán (CULI) and (c) La Paz (LPAZ).

it can be observed that the three antennas are placed on top of buildings and some local structures located in the surrounding antenna environment might be a potential source or contributor of the evident multipath existence. Figure 6 presents the pseudorange multipath time-series for the most affected GPS sites (SA61, CIC1 and CORX), that are associated to SNG and SCIGN arrays. In Figure 6(a) variations for SA61 are within 40 to $50 \mathrm{~cm}$, but with some disperse values (at the beginning of 2011) that can be attributed to some cause other than a change in hardware. There is not a convincing argument of what could cause these higher values around 2011. SA61 is found to be the most contaminated site of the SNG network as compared to SG21, OXEC and UCOM stations. An ascending trend on the pseudorange multipath variation results can be observed at the end of 2009 for CIC1 site as illustrated in Figure 6(b). Unfortunately there is no more data after that year, with which to further investigate multipath at this station. Multipath at site CORX also exhibits unusual behavior; with the multipath RMS values dropping at the end of 2003, see Figure 6(c). This drop may be attributed to a change in the antenna that occurred in mid November when the ASH701945B_M was replaced by the ASH701945C_M antenna; since no replacement on the GPS receiver is documented for this site.

Figure 7 shows the three most (PHJX, PTEX and PLTX) and three least (PLPX, PTAX and PJZX) affected sites from the PBO network, respectively. The scatter for the most affected stations ranges from 25 to $50 \mathrm{~cm}$, while less affected sites fluctuate between 20 and $30 \mathrm{~cm}$. Even thought, PLPX, PTAX and PJZX are the sites that experienced smallest amounts of pseudorange multipath effects (ranked over all PBO stations in Mexico) an evident annual behavior can be observed on the variation results at these sites. Panoramic pictures for the three most affected (PHJX, PTEX and PLTX) PBO sites are shown in Figure 8, courtesy of [20]. The antennas for the PBO stations are mounted on shallow-braced monuments in open fields, where the most likely source of multipath is the ground surface in the vicinity of the monuments. Reference [11] demonstrated that antenna height estimates and MP1-RMS or MP2-RMS variation time-series

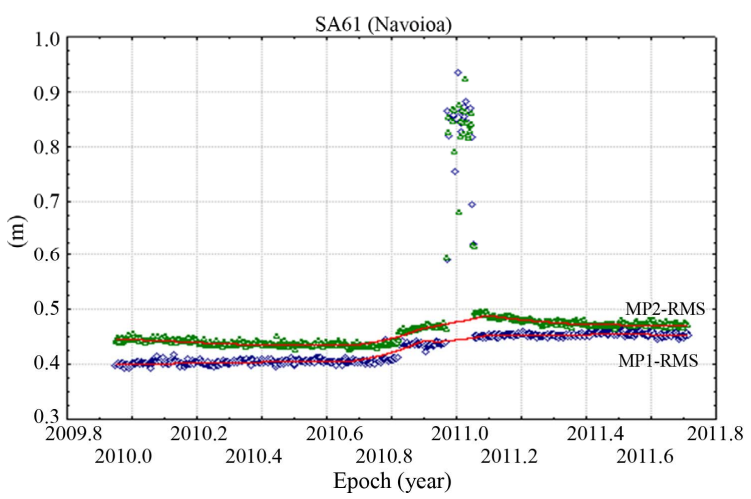

(a)

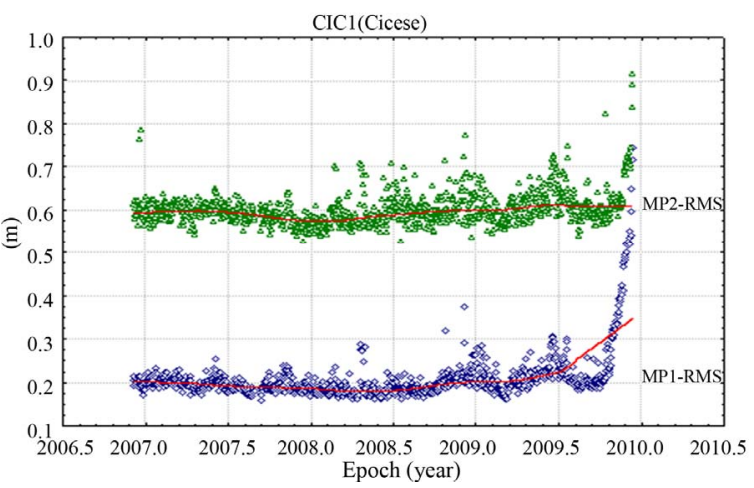

(b)

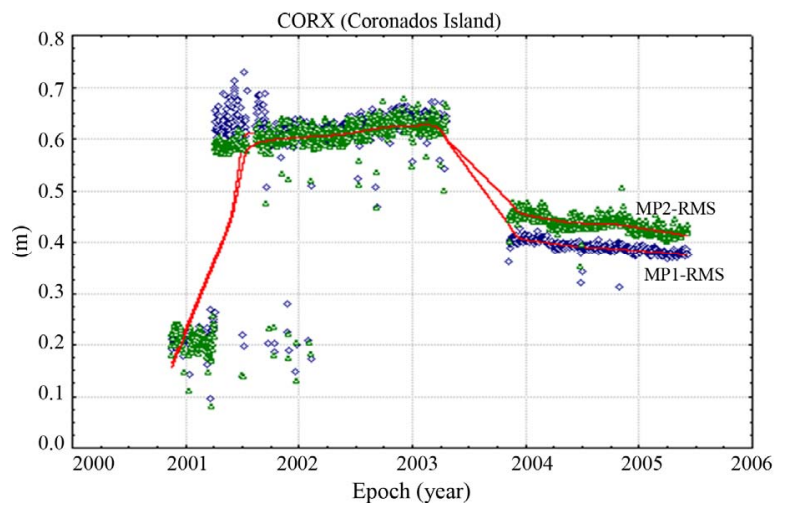

(c)

Figure 6. Pseudorange multipath MP1-RMS and MP2-RMS variations, most affected sites: (a) Navojoa (SA61), SNG network; (b) Cicese (CIC1), SCIGN network and Coronados Island (CORX), SCIGN network. 


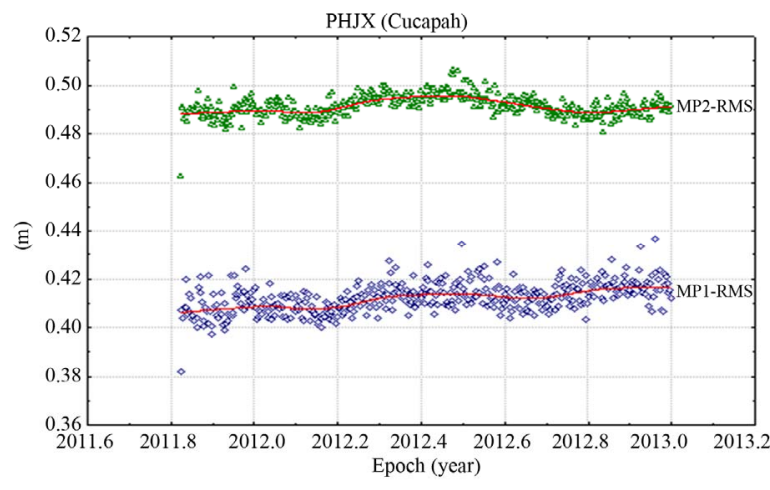

(a)

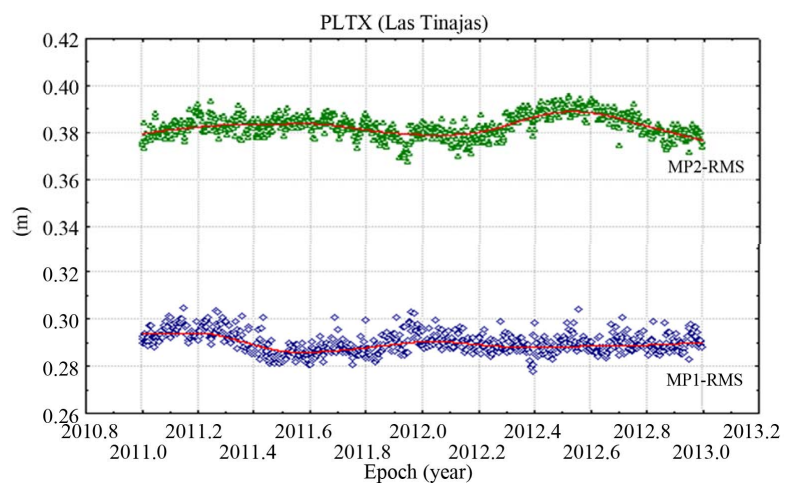

(c)

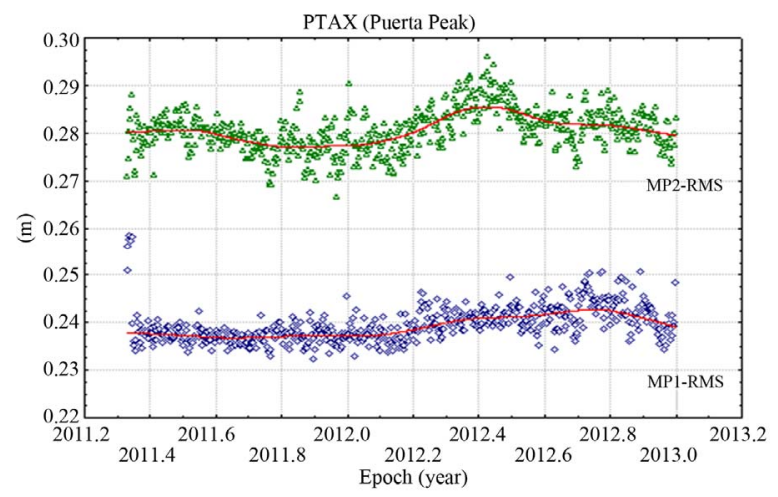

(e)

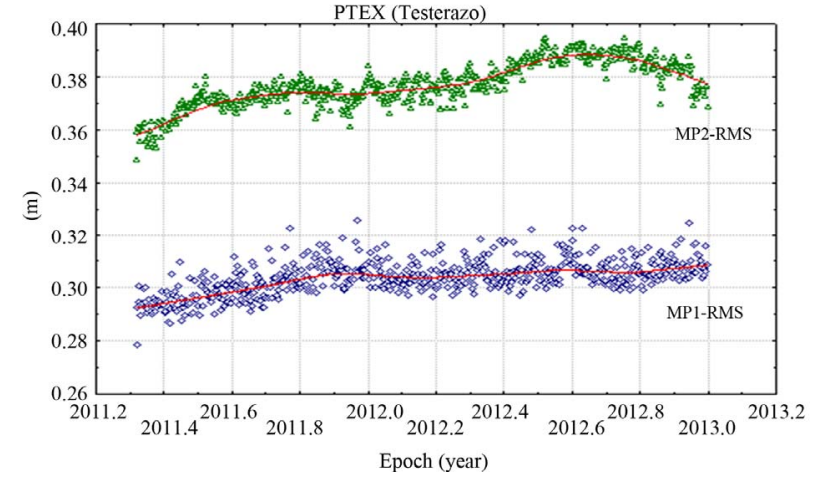

(b)

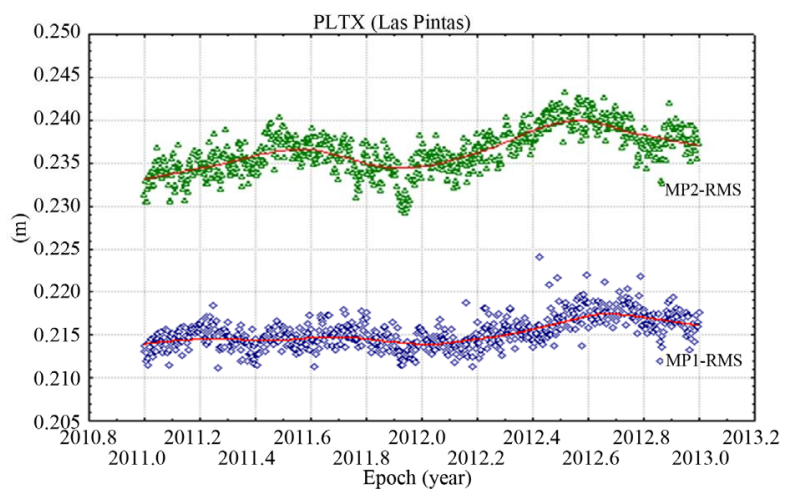

(d)

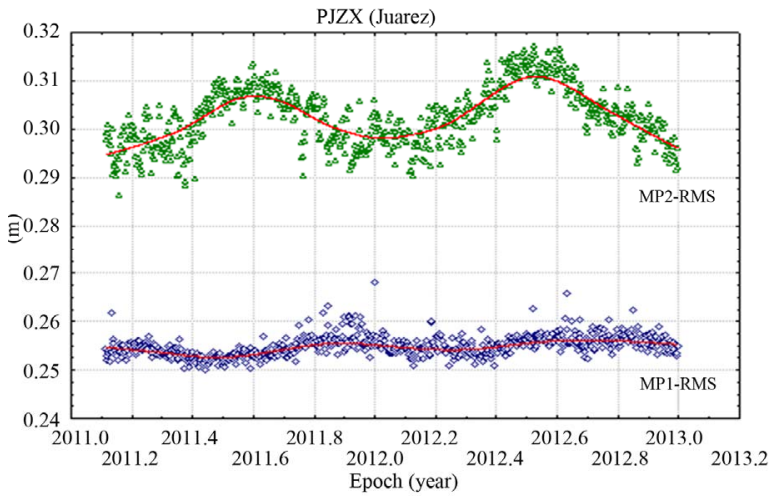

(f)

Figure 7. Pseudorange multipath MP1-RMS and MP2-RMS variations, most affected sites: (a) Cucapah (PHJX); (b) Testerazo (PTEX); (c) Las Tinajas (PLTX) and least affected sites: (d) Las Pintas (PLPX); (e) Puerta Peak (PTAX); (f) Sr. Juárez (PJZX), PBO network.

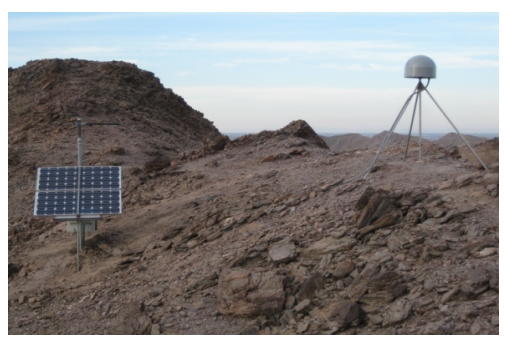

(a)

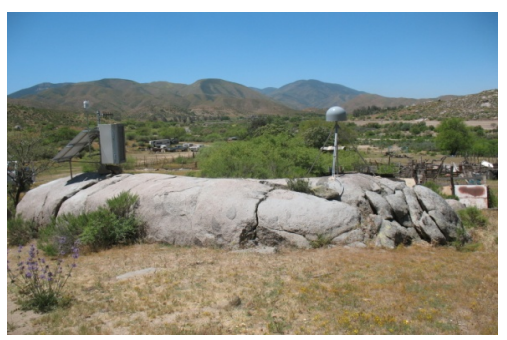

(b)

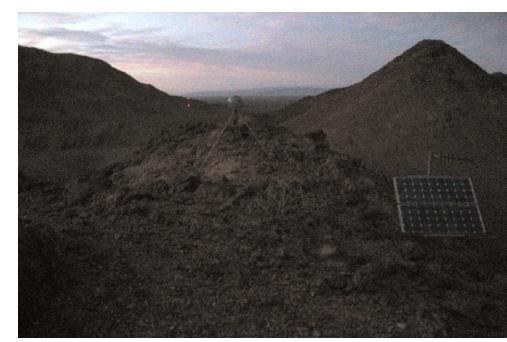

(c)

Figure 8. PBO network: (a) HJ Cucapah (PHJX) site, date of photo October, 2011; (b) Testerazo (PTEX) site, date of photo April, 2011; Las Tinajas (PLTX) site, date of photo October, 2010. 
are highly correlated. This is illustrated for the Mexico $\mathrm{PBO}$ sites in Figure 9. Prominent annual variations are apparent in both the height and the MP2-RMS time series, coincident with one another. The peak values for height as well as for the MP2-RMS variations were encountered at the middle of 2011 and 2012, respectively. There are several possible explanations for this coincidence, including a potential instrumental response that may be attributed to some primary seasonal forcing, inappropriate modeling in the GPS data analysis, and the presence of the remaining multipath effects in the final positioning estimates. However, this fact needs further investigation

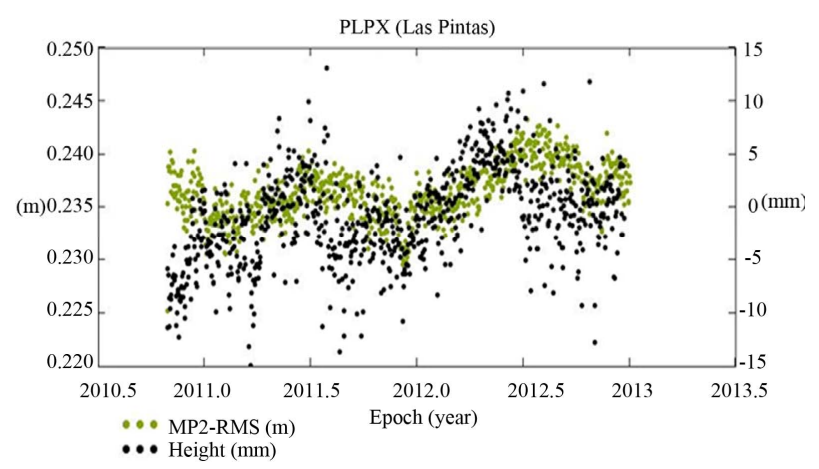

(a)

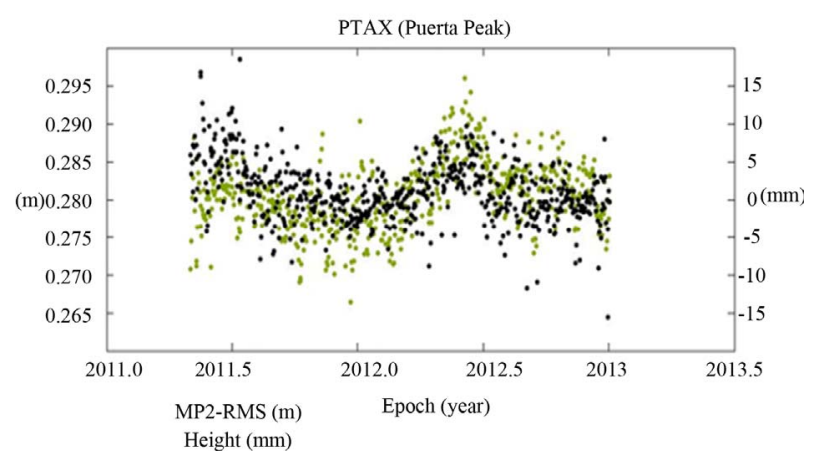

(b)

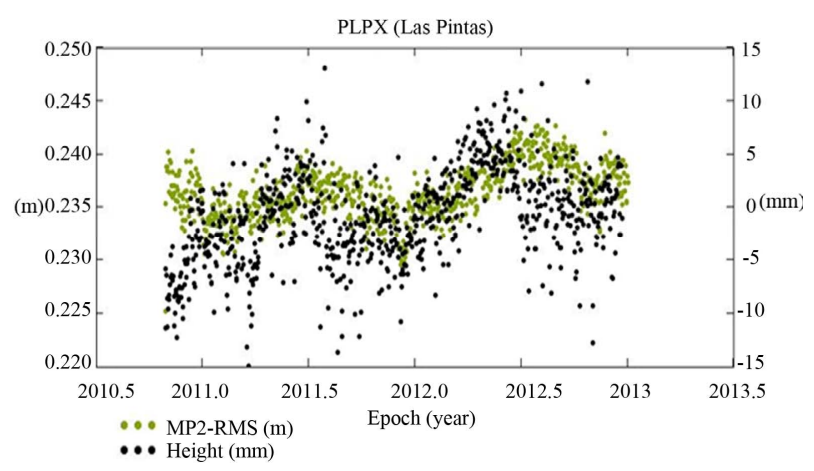

(c)

Figure 9. Time-series for height component (right scale in mm.) and MP2-RMS (left scale in m.), PBO network: (a) Las Pintas (PLPX) site; (b) Puerta Peak (PTAX) site; (c) Sr. Juarez (PJZX) site. in order to demonstrate and understand more what is causing these coincidences.

Cayaco (CAYA) belongs to the GPS network from UNAM, and is located at the Pacific coast in the Guerrero region and it was the only continuous station in operation in 1998, allowing for the first detection of silent earthquake phenomena associated with the Middle America trench near Guerrero, Mexico [9]. CAYA is the only site considered in the experiment that uses a LEICA SR530 receiver and a TRIMBLE Geodetic L1/L2 (TRM22020.00) antenna. Comparing this site among to all the analyzed stations, CAYA was found to be one of the most affected sites. Even though, CAYA's results approximately range within 30 to $70 \mathrm{~cm}$ from 1997 to 2002. There is an evident jump immediately after that year reaching values up to $2.2 \mathrm{~m}$, see Figure 10(a). It is suspected that this fact might be attributed to a change in the hardware, since prior to 2002 CAYA used a TRIMBLE 4000SSE GPS receiver. However, a drop can be seen in the results at the end of 2003 and this issue may be attributed to an update in the firmware version of the LEICA SR530 GPS receiver from 4.01 to 4.22. Based on the GPS data availability, Yautepec (YAIG) is another station from the UNAM network considered in the experiment. It is located in the Morelos region and its main objective, since it was installed in 1999, is to investigate possible displacements associated with the slow slip event that first started sometime during mid-November to early December 2001 [17]. The MP1-RMS and MP2RMS variations for this site are as high as $85 \mathrm{~cm}$, see Figure 10(b); ranked overall stations at sixth place. A gap in the data can be observed between 2001 and 2003 and part of 2004. There is no basis to argue that the drop of the results during these times can be attributed to any replacement in the hardware, since the same receiver (Ashtech Z-12) and antenna type (ASH700936E_C) remained at this site from August 2002 up to the last date it recorded GPS data. Finally, results for the most affected site (MPR1) from the CORS network is illustrated in Figure 10(c). Here, MPR1 site shows a scatter for both MP1-RMS and MP2-RMS that ranges roughly from 80 to $110 \mathrm{~cm}$; that is why MPR1 site is ranked first among the other CORS sites and overall ranked fourth highest for MP1-RMS and third highest for MP2-RMS (see Tables 2 and 3) among all tested sites. Tables 2 and $\mathbf{3}$ show the statistics (in units of centimeters) for the MP1-RMS and MP2-RMS variations at all tested GPS stations. The NGS designator for the type of GPS receiver and antenna used are included as well as the name of the station, the number of available days of data and the acronym of the array to which they belong. CGPS stations were ranked from the most to the least affected based on their max and min values. However, an important issue here is that all sites present a great variety of GPS data availability, 
Table 2. Statistics of the MP1-RMS variations for CGPS sites spanning Mexico.

\begin{tabular}{|c|c|c|c|c|c|c|c|c|c|}
\hline Rank (Order) & Site & $\begin{array}{l}\text { No. of } \\
\text { Days }\end{array}$ & $\operatorname{Max}(\mathbf{c m})$ & $\operatorname{Min}(\mathbf{c m})$ & Mean $(\mathbf{c m})$ & $\begin{array}{c}\text { St. } \\
\text { Dev. } \pm(\mathbf{c m})\end{array}$ & Receiver Type & Antenna Type & GPS Array \\
\hline 1 & MEXI & 5432 & 338.03 & 5.13 & 87.46 & 112.7 & TRIMBLE 5700 & TRM41249.00 & RGNA \\
\hline 2 & CULI & 2747 & 301.83 & 4.16 & 110.83 & 115.2 & TRIMBLE 5700 & TRM41249.00 & RGNA \\
\hline 3 & LPAZ & 5909 & 271.16 & 9.24 & 99.47 & 104.7 & TRIMBLE 5700 & TRM41249.00 & RGNA \\
\hline 4 & MPR1 & 1652 & 106.36 & 61.67 & 93.10 & 4.33 & NOV WAASGII & MPL WAAS 2225NW & CORS \\
\hline 5 & CAYA & 2136 & 106.07 & 3.49 & 40.56 & 17.14 & LEICA SR530 & TRM22020.00 & UNAM \\
\hline 6 & MTP1 & 1348 & 105.31 & 64.35 & 86.01 & 4.23 & NOV WAASGII & MPL WAAS 2225NW & CORS \\
\hline 7 & MSD1 & 1623 & 97.35 & 60.18 & 81.46 & 3.84 & NOV WAASGII & MPL WAAS 2225NW & CORS \\
\hline 8 & SA61 & 637 & 93.32 & 39.16 & 44.17 & 8.19 & TRIMBLE 4700 & TRM33429.20 & SNG \\
\hline 9 & INEG & 3704 & 85.56 & 4.44 & 17.45 & 20.4 & TRIMBLE 5700 & TRM29659.00 & RGNA \\
\hline 10 & DOAR & 1435 & 85.48 & 3.32 & 55.29 & 24.32 & ASHTECH UZ12 & ASH701945E_M & UNAM \\
\hline 11 & MMD1 & 1655 & 84.26 & 55.81 & 71.19 & 1.92 & NOV WAASGII & MPL WAAS 2225NW & CORS \\
\hline 12 & CIC1 & 1083 & 74.33 & 15.82 & 20.91 & 5.90 & ROGUE SNR8000 & AOAD/M_T & SCIGN \\
\hline 13 & MMX1 & 1639 & 69.57 & 50.99 & 59.56 & 1.80 & NOV WAASGII & MPL WAAS $2225 \mathrm{NW}$ & CORS \\
\hline 14 & CORX & 1387 & 67.58 & 8.06 & 49.84 & 12.81 & ASHTECH ZII3 & ASH701945C_M & SCIGN \\
\hline 15 & YAIG & 1181 & 59.79 & 3.45 & 35.92 & 11.64 & ASHTECH ZII3 & ASH700936E_C & UNAM \\
\hline 16 & IITJ & 2898 & 55.02 & 34.79 & 46.20 & 1.54 & TRIMBLE 4400 & TRM23903.00 & RGNA \\
\hline 17 & OXEC & 498 & 53.15 & 36.82 & 38.98 & 2.59 & TRIMBLE NETRS & TRM41249.00 & SNG \\
\hline 18 & IMIE & 342 & 52.09 & 25.84 & 36.70 & 2.24 & TRIMBLE NETR9 & TRM55971.00 & RGNA \\
\hline 19 & GUAX & 973 & 50.85 & 34.27 & 39.00 & 1.11 & ASHTECH ZII3 & ASH701945C_M & SCIGN \\
\hline 20 & SPMX & 216 & 46.56 & 36.58 & 43.09 & 1.68 & ASHTECH ZII3 & ASH701945B_M & SCIGN \\
\hline 21 & PHJX & 428 & 43.65 & 38.18 & 41.20 & 0.61 & TRIMBLE NETR9 & TRM59800.00 & PBO \\
\hline 22 & UCOM & 460 & 38.01 & 32.41 & 34.75 & 0.85 & TRIMBLE NETRS & TRM41249.00 & SNG \\
\hline 23 & USMX & 1468 & 37.87 & 29.94 & 31.86 & 0.81 & TRIMBLE NETRS & ASH701945B_M & SCIGN \\
\hline 24 & SG21 & 1071 & 37.42 & 27.83 & 30.42 & 1.62 & TRIMBLE 4700 & TRM33429.20 & SNG \\
\hline 25 & CHET & 2622 & 36.03 & 9.28 & 15.38 & 3.98 & TRIMBLE 5700 & TRM41249.00 & RGNA \\
\hline 26 & VIL2 & 1062 & 35.71 & 12.65 & 16.28 & 3.35 & TRIMBLE 5700 & TRM41249.00 & RGNA \\
\hline 27 & CULC & 1074 & 35.63 & 10.12 & 13.82 & 1.55 & TRIMBLE 5700 & TRM41249.00 & RGNA \\
\hline 28 & HER2 & 3581 & 35.23 & 6.73 & 14.94 & 2.82 & TRIMBLE 5700 & TRM41249.00 & RGNA \\
\hline 29 & YESX & 181 & 35.21 & 32.78 & 33.76 & 0.43 & TRIMBLE NETRS & ASH701945B_M & SCIGN \\
\hline 30 & COL2 & 2622 & 34.64 & 11.80 & 19.02 & 6.15 & TRIMBLE 5700 & TRM41249.00 & RGNA \\
\hline 31 & TOL2 & 2612 & 33.95 & 5.39 & 12.85 & 3.66 & TRIMBLE 5700 & TRM41249.00 & RGNA \\
\hline 32 & UQRO & 711 & 33.82 & 18.58 & 24.39 & 2.27 & ASHTECH ZII3 & ASH700228D & RGNA \\
\hline 33 & IDGO & 1065 & 33.76 & 26.73 & 30.12 & 0.70 & ASHTECH ZII3 & ASH700228D & RGNA \\
\hline 34 & MTY2 & 2627 & 33.04 & 6.20 & 12.88 & 2.20 & TRIMBLE 5700 & TRM41249.00 & RGNA \\
\hline 35 & MERI & 2637 & 32.64 & 8.10 & 12.90 & 3.01 & TRIMBLE 5700 & TRM41249.00 & RGNA \\
\hline 36 & PTEX & 612 & 32.56 & 27.86 & 30.38 & 0.64 & TRIMBLE NETRS & TRM59800.00 & PBO \\
\hline 37 & OAX2 & 2629 & 32.23 & 4.39 & 12.78 & 2.66 & TRIMBLE 5700 & TRM41249.00 & RGNA \\
\hline 38 & IMIP & 1034 & 32.2 & 29.81 & 30.87 & 0.46 & TRIMBLE 5700 & TRM41249.00 & RGNA \\
\hline 39 & CAM2 & 1152 & 31.90 & 5.32 & 12.68 & 3.19 & TRIMBLE 5700 & TRM41249.00 & RGNA \\
\hline 40 & TAMP & 1049 & 30.91 & 11.40 & 15.23 & 1.94 & TRIMBLE 5700 & TRM41249.00 & RGNA \\
\hline 41 & ICAM & 1086 & 30.72 & 10.39 & 14.05 & 3.50 & TRIMBLE 5700 & TRM41249.00 & RGNA \\
\hline 42 & CHI3 & 1087 & 30.62 & 9.33 & 13.28 & 1.82 & TRIMBLE 5700 & TRM41249.00 & RGNA \\
\hline 43 & PLTX & 792 & 30.45 & 27.76 & 28.97 & 0.45 & TRIMBLE NETRS & TRM29659.00 & PBO \\
\hline 44 & ICEP & 1004 & 29.75 & 17.76 & 20.59 & 1.31 & ASHTECH ZII3 & ASH700228D & RGNA \\
\hline 45 & USLP & 1042 & 29.18 & 19.54 & 23.62 & 1.07 & ASHTECH ZII3 & ASH700228D & RGNA \\
\hline 46 & PALX & 728 & 29.04 & 25.68 & 26.83 & 0.44 & TRIMBLE NETRS & TRM59800.00 & PBO \\
\hline 47 & UGTO & 1063 & 28.62 & 7.99 & 12.01 & 2.51 & TRIMBLE 5700 & TRM41249.00 & RGNA \\
\hline 48 & PSTX & 850 & 27.43 & 24.21 & 25.71 & 0.49 & TRIMBLE NETRS & TRM59800.00 & PBO \\
\hline 49 & PJZX & 686 & 26.79 & 24.99 & 25.48 & 0.21 & TRIMBLE NETRS & TRM59800.80 & PBO \\
\hline 50 & PTAX & 609 & 25.82 & 23.21 & 23.94 & 0.37 & TRIMBLE NETRS & ASH701945B_M & PBO \\
\hline 51 & UVER & 229 & 25.25 & 11.76 & 14.06 & 1.83 & ASHTECH ZII3 & ASH700228D & RGNA \\
\hline 52 & PLPX & 794 & 22.40 & 21.10 & 21.52 & 0.18 & TRIMBLE NETRS & TRM59800.80 & PBO \\
\hline 53 & IPAZ & 346 & 19.85 & 11.95 & 14.83 & 1.13 & TRIMBLE 5700 & TRM41249.00 & RGNA \\
\hline
\end{tabular}


Table 3. Statistics of the MP2-RMS variations for CGPS sites spanning Mexico.

\begin{tabular}{|c|c|c|c|c|c|c|c|c|c|}
\hline $\begin{array}{c}\text { Rank } \\
\text { (Order) }\end{array}$ & Site & $\begin{array}{l}\text { No. of } \\
\text { Days }\end{array}$ & $\operatorname{Max}(\mathbf{c m})$ & $\operatorname{Min}(\mathbf{c m})$ & Mean (cm) & $\begin{array}{c}\text { St. Dev. } \\
\pm(\mathbf{c m})\end{array}$ & Receiver Type & Antenna Type & GPS Array \\
\hline 1 & CAYA & 2136 & 216.43 & 7.64 & 55.77 & 31.32 & LEICA SR530 & TRM22020.00 & UNAM \\
\hline 2 & IITJ & 2898 & 129.14 & 49.73 & 98.02 & 7.11 & TRIMBLE 4400 & TRM23903.00 & RGNA \\
\hline 3 & MPR1 & 1652 & 120.62 & 73.64 & 101.44 & 4.38 & NOV WAASGII & MPL WAAS 2225NW & CORS \\
\hline 4 & MTP1 & 1348 & 109.44 & 72.04 & 94.97 & 4.76 & NOV WAASGII & MPL WAAS 2225NW & CORS \\
\hline 5 & MSD1 & 1623 & 104.01 & 61.71 & 90.53 & 4.55 & NOV WAASGII & MPL WAAS 2225NW & CORS \\
\hline 6 & SA61 & 637 & 92.28 & 42.62 & 46.93 & 7.32 & TRIMBLE 4700 & TRM33429.20 & SNG \\
\hline 7 & CIC1 & 1083 & 91.52 & 52.41 & 60.06 & 3.87 & ROGUE SNR8000 & AOAD/M_T & SCIGN \\
\hline 8 & MMD1 & 1655 & 86.92 & 57.17 & 79.14 & 2.49 & NOV WAASGII & MPL WAAS 2225NW & CORS \\
\hline 9 & DOAR & 1435 & 85.18 & 6.79 & 57.49 & 21.12 & ASHTECH UZ12 & ASH701945E_M & UNAM \\
\hline 10 & YAIG & 1181 & 85.00 & 8.14 & 42.76 & 11.45 & ASHTECH ZII3 & ASH700936E_C & UNAM \\
\hline 11 & LPAZ & 5909 & 74.79 & 20.89 & 39.65 & 12.1 & TRIMBLE 5700 & TRM41249.00 & RGNA \\
\hline 12 & CORX & 1387 & 72.85 & 9.57 & 48.61 & 14.41 & ASHTECH ZII3 & ASH701945C_M & SCIGN \\
\hline 13 & MEXI & 5432 & 70.86 & 12.82 & 34.94 & 14.6 & TRIMBLE 5700 & TRM41249.00 & RGNA \\
\hline 14 & MMX1 & 1639 & 69.88 & 50.36 & 58.90 & 1.35 & NOV WAASGII & MPL WAAS 2225NW & CORS \\
\hline 15 & IMIE & 342 & 65.28 & 39.08 & 45.10 & 2.11 & TRIMBLE NETR9 & TRM55971.00 & RGNA \\
\hline 16 & COL2 & 2622 & 60.82 & 31.56 & 40.65 & 7.26 & TRIMBLE 5700 & TRM41249.00 & RGNA \\
\hline 17 & IDGO & 1065 & 55.54 & 41.57 & 48.16 & 1.72 & ASHTECH ZII3 & ASH700228D & RGNA \\
\hline 18 & CHET & 2622 & 54.54 & 19.35 & 26.88 & 4.39 & TRIMBLE 5700 & TRM41249.00 & RGNA \\
\hline 19 & CULI & 2747 & 54.31 & 4.17 & 26.34 & 17.56 & TRIMBLE 5700 & TRM41249.00 & RGNA \\
\hline 20 & INEG & 3704 & 54.16 & 10.06 & 26.01 & 12.3 & TRIMBLE 5700 & TRM29659.00 & RGNA \\
\hline 21 & GUAX & 973 & 54.05 & 35.13 & 41.83 & 1.42 & ASHTECH ZII3 & ASH701945C_M & SCIGN \\
\hline 22 & OXEC & 498 & 53.40 & 39.80 & 42.04 & 2.10 & TRIMBLE NETRS & TRM41249.00 & SNG \\
\hline 23 & IMIP & 1034 & 51.94 & 45.07 & 47.70 & 0.84 & TRIMBLE 5700 & TRM41249.00 & RGNA \\
\hline 24 & OAX2 & 2629 & 51.63 & 7.90 & 19.84 & 4.54 & TRIMBLE 5700 & TRM41249.00 & RGNA \\
\hline 25 & PHJX & 428 & 50.64 & 46.26 & 49.13 & 0.44 & TRIMBLE NETR9 & TRM59800.00 & PBO \\
\hline 26 & SPMX & 216 & 50.53 & 40.31 & 46.39 & 2.08 & ASHTECH ZII3 & ASH701945B_M & SCIGN \\
\hline 27 & VIL2 & 1062 & 50.43 & 24.84 & 29.69 & 3.76 & TRIMBLE 5700 & TRM41249.00 & RGNA \\
\hline 28 & CULC & 1074 & 48.37 & 24.59 & 28.37 & 1.59 & TRIMBLE 5700 & TRM41249.00 & RGNA \\
\hline 29 & TOL2 & 2612 & 46.79 & 11.88 & 22.26 & 4.03 & TRIMBLE 5700 & TRM41249.00 & RGNA \\
\hline 30 & UCOM & 460 & 46.74 & 40.41 & 43.28 & 1.06 & TRIMBLE NETRS & TRM41249.00 & SNG \\
\hline 31 & HER2 & 3581 & 46.49 & 12.00 & 28.08 & 3.70 & TRIMBLE 5700 & TRM41249.00 & RGNA \\
\hline 32 & TAMP & 1049 & 46.13 & 23.70 & 27.26 & 2.34 & TRIMBLE 5700 & TRM41249.00 & RGNA \\
\hline 33 & MERI & 2637 & 45.89 & 17.00 & 26.32 & 3.17 & TRIMBLE 5700 & TRM41249.00 & RGNA \\
\hline 34 & MTY2 & 2627 & 44.86 & 12.30 & 21.41 & 2.42 & TRIMBLE 5700 & TRM41249.00 & RGNA \\
\hline 35 & ICAM & 1086 & 44.19 & 20.50 & 25.94 & 3.74 & TRIMBLE 5700 & TRM41249.00 & RGNA \\
\hline 36 & ICEP & 1004 & 42.92 & 24.96 & 29.01 & 2.11 & ASHTECH ZII3 & ASH700228D & RGNA \\
\hline 37 & SG21 & 1071 & 42.70 & 27.87 & 33.93 & 2.80 & TRIMBLE 4700 & TRM33429.20 & SNG \\
\hline 38 & CHI3 & 1087 & 42.62 & 21.89 & 24.85 & 2.01 & TRIMBLE 5700 & TRM41249.00 & RGNA \\
\hline 39 & UQRO & 711 & 41.80 & 20.06 & 27.85 & 3.93 & ASHTECH ZII3 & ASH700228D & RGNA \\
\hline 40 & CAM2 & 1152 & 41.36 & 11.67 & 19.01 & 3.59 & TRIMBLE 5700 & TRM41249.00 & RGNA \\
\hline 41 & PLTX & 792 & 39.55 & 36.74 & 38.30 & 0.49 & TRIMBLE NETRS & TRM29659.00 & PBO \\
\hline 42 & PTEX & 612 & 39.45 & 34.82 & 37.69 & 0.85 & TRIMBLE NETRS & TRM59800.00 & PBO \\
\hline 43 & USMX & 1468 & 38.74 & 33.06 & 34.73 & 0.69 & TRIMBLE NETRS & ASH701945B_M & SCIGN \\
\hline 44 & YESX & 181 & 38.44 & 34.77 & 36.85 & 0.77 & TRIMBLE NETRS & ASH701945B_M & SCIGN \\
\hline 45 & USLP & 1042 & 37.66 & 23.24 & 30.33 & 1.44 & ASHTECH ZII3 & ASH700228D & RGNA \\
\hline 46 & IPAZ & 346 & 37.60 & 25.86 & 29.38 & 1.63 & TRIMBLE 5700 & TRM41249.00 & RGNA \\
\hline 47 & PSTX & 850 & 36.85 & 30.24 & 33.86 & 1.23 & TRIMBLE NETRS & TRM59800.00 & РBO \\
\hline 48 & UVER & 229 & 35.31 & 16.69 & 19.31 & 2.36 & ASHTECH ZII3 & ASH700228D & RGNA \\
\hline 49 & PALX & 728 & 34.36 & 29.83 & 32.52 & 0.80 & TRIMBLE NETRS & TRM59800.00 & PBO \\
\hline 50 & UGTO & 1063 & 32.13 & 11.73 & 17.52 & 3.06 & TRIMBLE 5700 & TRM41249.00 & RGNA \\
\hline 51 & PJZX & 686 & 31.73 & 28.62 & 30.25 & 0.61 & TRIMBLE NETRS & TRM59800.80 & PBO \\
\hline 52 & PTAX & 609 & 29.60 & 26.63 & 28.05 & 0.44 & TRIMBLE NETRS & ASH701945B_M & PBO \\
\hline 53 & PLPX & 794 & 24.33 & 22.93 & 23.64 & 0.26 & TRIMBLE NETRS & TRM59800.80 & PBO \\
\hline
\end{tabular}




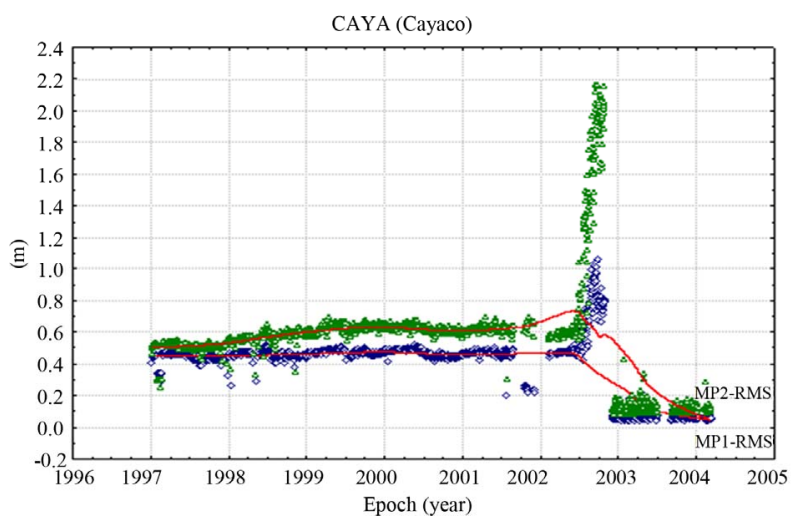

(a)

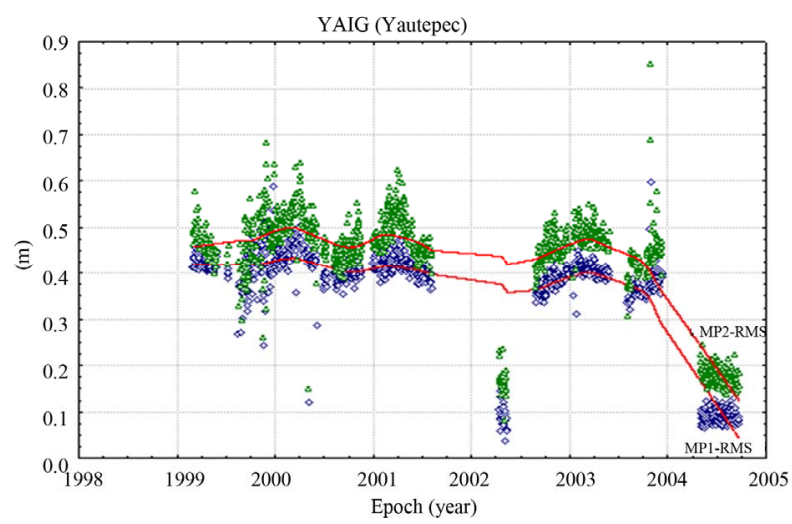

(b)

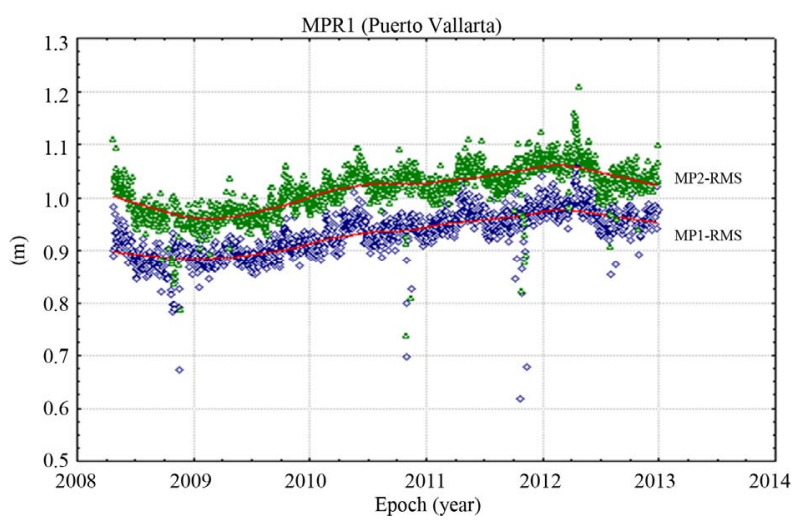

(c)

Figure 10. Pseudorange multipath (MP1-RMS and MP2RMS) variations, most affected sites: (a) Cayaco (CAYA) and Yautepec (YAIG), UNAM network and (c) Puerto Vallarta (MPR1), CORS network.

ranging from almost one to several years.

\section{Conclusion}

Based on the presented pseudorange assessment and analysis, it can be concluded that MEXI, CULI and LPAZ sites, as part of the RGNA network, were the three most affected (meter level) on the MP1-RMS results. However, recalling that prior to 2000, there was only
C/A code available for these stations, there was no solution for the MP2-RMS and the only solution reported for the MP1-RMS was based on this code. After 2000, and derived from the MP2-RMS results, these sites reduced their rank amongst all stations to $11^{\text {th }}, 13^{\text {th }}$ and $19^{\text {th }}$ highest, respectively. In addition, the cooperative station belonging to the RGNA network and controlled by the IITJ was positioned $16^{\text {th }}$ and $2^{\text {nd }}$, while INEGI's site, which was the only station of the RGNA that used a Trimble Choke-Ring antenna was ranked $9^{\text {th }}$ and $20^{\text {th, }}$ respectively. On the other hand, site CAYA that belongs to the UNAM network was considered as one of the most affected sites; ranking in $1^{\text {st }}$ place for the MP2-RMS and $5^{\text {th }}$ for the MP1-RMS. Sites SA61 and YAIG from the SNG and UNAM networks respectively, as well as all the sites from the CORS network were located within the top fifteen sites for highest MP1-RMS and MP2-RMS values. The least affected CGPS sites (PLPX, PTAX and PJZX) belong to the PBO network; they experienced the smallest amounts of pseudorange multipath among all stations for MP2-RMS, and in the lowest 10 percent for MP1-RMS. Possible reasons for high multipath at some of the analyzed CGPS stations can be attributed to issues related to GPS hardware replacement (i.e., receiver and antenna type or receiver firmware version), to the existence of the antenna radome, and/or the antenna enviroment (vegetation, constructions, local structures and rocks). The annual seasonal effect for the pseudorange multipath vs. height variations (presented in the form of time-series) shows a reasonable level of agreement or coincidence between these two types of solutions; however, this issue requires further investigation. It is expected that pseudorange multipath can be used for further data cleaning to improve positioning results, together with an assessment of ionospheric and tropospheric effects and carrier phase multipath.

\section{Acknowledgements}

The authors would like to thank UNAVCO, PBO, INEGI, IITJ, SCIGN, USGS, JPL, UNAM, SNG and CORS networks, for making the GPS data publicly available for the analysis. This research is funded by a postdoctoral scholarship (186766) from the National Council of Science and Technology (CONACYT).

\section{REFERENCES}

[1] A. Bilich and K. M. Larson, "Mapping the GPS Multipath Environment Using the Signal-to-Noise Ratio (SNR)," Radio Science, Vol. 42, No. 6, 2007, pp. 1-16. doi:10.1029/2007RS003652

[2] P. Elósegui, J. L. Davis, R. K. Jaldehag, J. M. Johansson, A. E. Niell and I. I. Shapiro, "Geodesy Using the Global Positioning System: The Effects of Signal Scattering on 
Estimates of Site Position," Journal of Geophysical Research: Solid Earth, Vol. 100, No. B6, 1995, pp. 99219934. doi:10.1029/95JB00868

[3] L. Estey and C. M. Meertens, "TEQC: The Multi-Purpose Toolkit for GPS/GLONASS Data,” GPS Solutions, Vol. 3, No. 1, 1999, pp. 42-49. doi:10.1007/PL00012778

[4] L. L. Ge, S. W. Han and C. Rizos, "Multipath Mitigation of Continuous GPS Measurements Using an Adaptive Filter,” GPS Solutions, Vol. 4, No. 2, 2000, pp. 19-30. doi:10.1007/PL00012838

[5] L. L. Ge, S. W. Han and C. Rizos, "GPS Multipath Change Detection in Permanent GPS Stations," Survey Review, Vol. 36, No. 283, 2002, pp. 306-322. doi:10.1179/003962602791483271

[6] S. Hilla and M. Cline, "Evaluating Pseudorange Multipath Effects at Stations in the National CORS Network," GPS Solutions, Vol. 8, No. 4, 2004, pp. 253-267. doi:10.1007/s10291-003-0073-3

[7] M. A. King and C. S. Watson, "Long GPS Coordinate Time Series: Multipath and Geometry Effects," Journal of Geophysical Research: Solid Earth, Vol. 115, No. B4, 2010. doi:10.1029/2009JB006543

[8] K. M. Larson, E. Gutmann, V. Zavorotny, J. Braun, M. Williams and F. Nievinski, "Can We Measure Snow Depth with GPS Receivers?” Geophysical Research Letters, Vol. 36, No. 17, 2009, pp. 1-5. doi:10.1029/2009GL039430

[9] A. R. Lowry, K. M. Larson, V. Kostoglodov and R. Bilham, "Tansient Fault Slip in Guerrero, Southern Mexico," Geophysical Research Letters, Vol. 28, No. 19, 2001, pp. 3753-3756. doi:10.1029/2001GL013238

[10] K. D. Park, P. Elósegui, J. L. Davis, P. O. J. Jarlemark, B. E. Corey, A. E. Niell, J. E. Normandeau, C. E. Meertens, and V. A. Andreatta, "Development of an Antenna and Multipath Calibration System for Global Positioning System Sites,” Radio Science, Vol. 39, No. 5, 2004, pp. 1-13. doi:10.1029/2003RS002999
[11] R. Jim, "Systematic Errors in GPS Position Estimates," IGS Workshop 2006, Darmstadt, 8-11 May 2006.

[12] C. Rizos and S. W. Han, "Quality Control Issues in Realtime GPS Positioning,” IUGG Congress, Birmingham, 18-30 July 1999.

[13] G. W. Roberts, X. Meng, A. H. Dodson and E. Cosser, "Multipath Mitigation for Bridge Deformation Monitoring,” Journal of Global Positioning System, Vol. 1, No. 1, 2002, pp. 25-33. doi:10.5081/jgps.1.1.25

[14] C. Satirapod, R. Khoonphool and C. Rizos, "Multipath Mitigation of Permanent GPS Stations Using Wavelets," International Symposium on GPS/GNSS, Tokyo, 15-18 November 2003, pp. 133-139.

[15] E. E. Small, K. M. Larson and J. J. Braun, "Sensing Vegetation Growth with Reflected GPS Signals,” Geophysical Research Letters, Vol. 37, No. , 2010, pp. 1-5. doi:10.1029/2010GL042951

[16] G. E. Vázquez and D. A. Grejner-Brzeziska, “A Case Study for Pseudorange Multipath Estimation and Analysis: TAMDEF GPS Network,” Geofísica Internacional, Vol. 51, No. 1, 2012, pp. 63-72.

[17] S. Yoshioka, T. Mikumo, V. Kostoglodov, K. M. Larson, A. R. Lowry and S. K. Singh, "Interplate Coupling and a Recent Aseismic Slow Slip Event in the Guerrero Seismic Gap of the Mexican Subduction Zone, as Deduced from GPS Data Inversion Using a Bayesian Information Criterion," Physics of the Earth and Planetary Interiors, Vol. 146, No. 3-4, 2004, pp. 513-530. doi:10.1016/j.pepi.2004.05.006

[18] http://facility.unavco.org/software/teqc/teqc.html

[19] UNAVCO, “QC v3 User Guide,” 1994. http://www.unavco.org

[20] http://pbo.unavco.org/station/overview/

[21] http://www.inegi.org.mx/

[22] http://usuarios.geofisica.unam.mx/ 